\title{
Active and recent deformation at the Southern Alps - Ligurian basin junction
}

\author{
C. Larroque ${ }^{1,2}$, N. Béthoux ${ }^{1}$, E. Calais ${ }^{1}$, F. Courboulex ${ }^{1}$, A. Deschamps ${ }^{1}$, \\ J. Déverchère ${ }^{1}$, J.-F. Stéphan ${ }^{1}$, J.-F. Ritz ${ }^{3} \&$ E. Gillii ${ }^{4}$
}

1 UMR Géosciences Azur, CNRS-Univ. de Nice Sophia Antipolis, 250 av. Einstein, 06560 Valbonne, France.

2 Laboratoire de Sciences de la Terre, Univ. de Reims, CRA, 2 esplanade R. Garros, 51100 Reims, France.

3 UMR Laboratoire de Géophysique, Tectonique et Sédimentologie, CNRS-Univ. de Montpellier II, 34095 Montpellier cedex 5, France.

4 Centre d'Etude du Karst, 13 rue Massena, 06000 Nice, France.

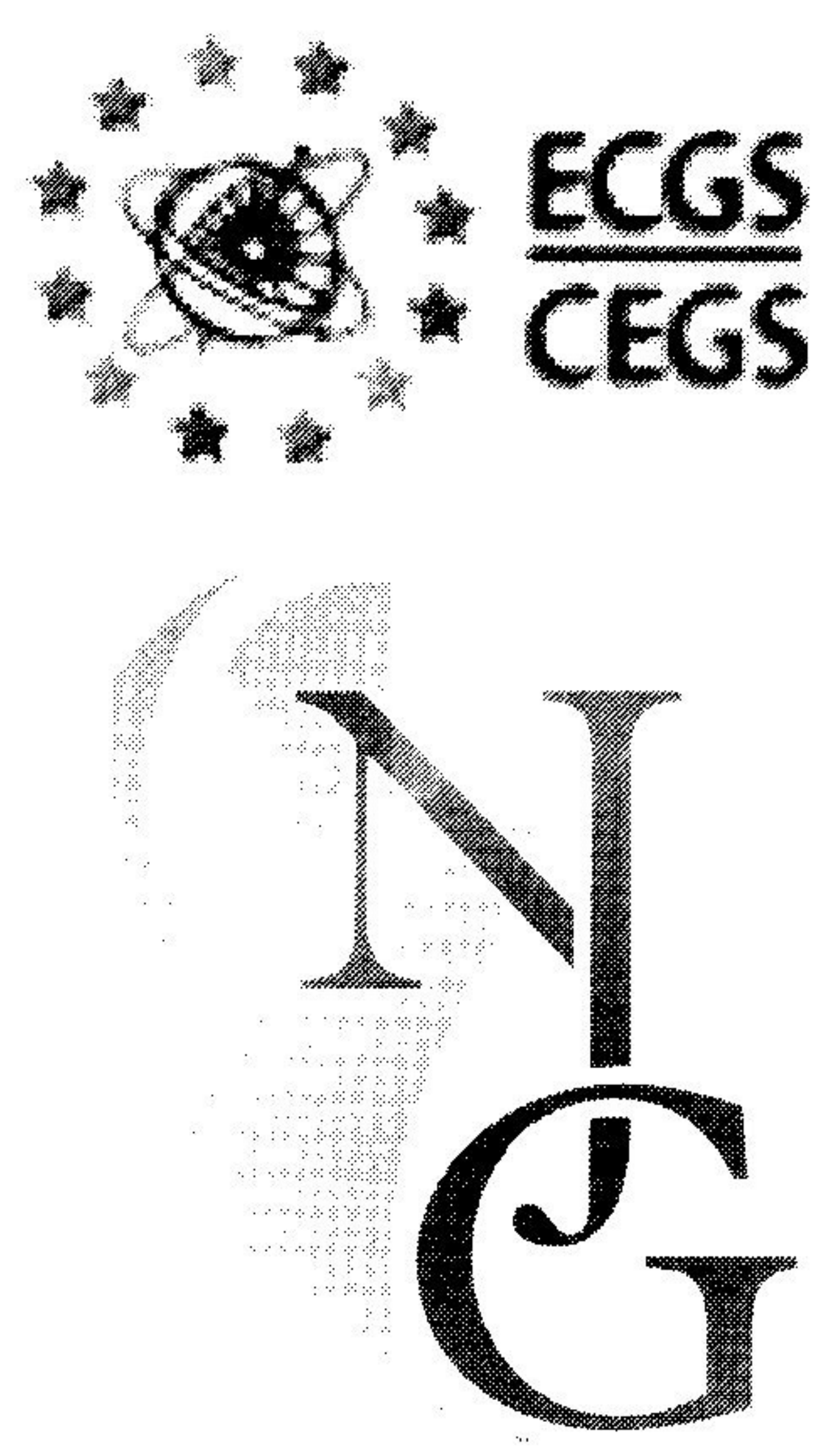

Manuscript received: December 1997; accepted: December 1999

\begin{abstract}
The Southern Alps - Ligurian basin junction is one of the most active seismic areas in Western Europe countries. The topographic and the structural setting of this region is complex because of (i) its position between the high topography of the Southern Alps and the deep, narrow Ligurian oceanic basin, and (ii) the large number of structures inherited from the Alpine orogeny. Historical seismicity reveals about twenty moderate-size earthquakes (up to $M=6.0$ ), mostly distributed along the Ligurian coast and the Vésubie valley. A recent geodetic experiment shows a significant strain rate during the last 50 years in the area between the Argentera massif and the Mediterranean coastline. Results of this experiment suggest a N-S shortening of about $2-4 \mathrm{~mm} / \mathrm{yr}$ over the network, this shortening direction is consistent with the seismological (P-axes of earthquakes) and the microtectonic data. The Pennic front (E-NE of the Argentera massif) and the northern Ligurian margin are the most seismically active areas. In the Nice arc and in the Argentera massif, some seismic lineaments correspond to faults identified in the field (such as the Taggia-Saorge fault or the Monaco-Sospel fault). In the western part of the Alpes Maritimes, no seismic activity is recorded in the Castellane arc. In the field, geological evidence, such as offsets of recent alluvial sediments, recent fault breccia, speleothem deformations, radon anomalies and others indicates recent deformation along these faults. Nevertheless, to this date active fault scarps have not been identified: this probably results from a relatively high erosion rate versus deformation rate and from the lack of Quaternary markers. We also suspect the presence of two hidden active faults, one in the lower Var valley (Nice city area) and the other one at the base of the Argentera crustal thrust-sheet. Offshore, along the northern Ligurian margin, the seismic reflection data shows traces of Quaternary extensional deformation, but the accuracy of the data does not yet allow the construction of a structural map nor does it allow the determination of the continuity between the offshore and onshore structures. From these data set we propose a preliminary map of 11 active faults and we discuss the questions which remain unsolved in the perspective of seismic hazard evaluations.
\end{abstract}

Keywords: Active fault, hidden fault, historical seismicity, Ligurian basin, Quaternary deformation, seismic hazard, Southern Alps

\section{Introduction}

Western European countries are presently considered as areas of low- to moderate seismicity. Nevertheless, because of the high vulnerability associated to most of these regions, some recent seismic events have involved dramatic social and material damages (e.g., 600 peoples died during the $1887, M=6.4$ Ligurian earthquake, e.g. Ferrari, 1991 and Laurenti, 1998).
Furthermore, paleoseismic investigations reveal strong earthquakes in European areas of present-day moderate activity, such as the Lower Rhine Embayment (Camelbeeck et al., 2000), as well as in areas of unknown historical activity, such as the Catalan coast range (Masana et al., 2000). The present-day seismicity at the junction between the Southern French Alps and the Ligurian Basin (the so-called "Alpes Maritimes» region) is one of the most active (high number 
of events and magnitude up to 6.0) among the western European countries. In addition, the vulnerability is also a major concern because of the 2.500 .000 inhabitants who are presently living between Cannes and Genoa and because of the numerous industries that set here.

The location, the maximum magnitude and the frequency of earthquakes are the basis of seismic hazard assessment. The parameters necessary for seismic hazard evaluations are quite difficult to estimate in areas of low deformation such as southeastern France. In spite of a well expressed seismicity, numerous problems remain that make this assessment a challenge, e.g.: (i) the deformation is distributed between onshore and offshore areas; and (ii) the lack of Quaternary deposits in onshore areas prevents the use of excavation methods, and consequently makes the determination of the reccurence intervals of earthquakes difficult.

We are currently performing an interdisciplinary study, involving instrumental seismology, geodesy, field tectonic and geomorphology (Larroque et al., 2000). The aim of this paper is first to summarize evidence of active deformation and to propose a schematic map of the active structures in this area. Afterwards, the objectives are to describe the geometry of the faults and their segmentation, and the relationships between onshore and offshore structures. From these observations and the paleoseismicity at regional scale, we attempt to better estimate the seismic hazard in the Alpes Maritmes.

\section{Tectonic and geomorphologic setting}

The studied area is located at the termination of the Southern French Alps between the high elevation crystalline massif of the Argentera and the low topographic Ligurian oceanic basin (A, Figure 1).

In the western mediterranean-alpine region, the deformations result mainly from (i) the convergence between the Africa and Eurasia plates since $100 \mathrm{My}$ and (ii) the opening of the narrow Liguro-Provençal oceanic basin. The convergence between the two plates currently occurs at a rate of $6.2+/-0.5 \mathrm{~mm} / \mathrm{yr}$ in a $163 \mathrm{~N}+/-9^{\circ}$ direction at the longitude of the Western Alps according to the Nuvel-1A plate motion model (DeMets et al., 1994). Although this far-field kinematic framework seems well-constrained, the kinematic of the present-day deformation within the Africa-Eurasia plate boundary in the Western Mediterranean remains poorly known because of the complex tectonic structures inherited from the 100 My alpine history and the low strain rate.

The Southern Alps- Ligurian basin junction is a highly complex geological region where three major geological units are joining: (1) the crystalline unit of the Argentera massif, (2) the sedimentary units of the southern subalpine massifs (the so-called "Castellane" and "Nice» arcs) overthrusting their foreland southward and (3) the small oceanic Ligurian basin with a steep and narrow northern margin. The Castellane and Nice arcs are a series of south-verging fold and thrusts involving the Mesozoic to Paleogene sediments, translated above a basal decollement zone in the upper triassic evaporites (Perez, 1975; Laurent, 1998; B, Figure 1). These subalpine nappes were previously the sedimentary cover of the Argentera massif. In the Southern Alps - Ligurian basin junction, the building of reliefs occured during two main steps since Oligocene time:

(1) Extensive phases, involved by a counterclockwise rotation of the Corsica-Sardinia block, leading to the opening of the Ligurian oceanic basin from 28 to $18 \mathrm{My}$ (Westphal et al., 1976).

(2) Compressive phases led to the emplacement of the Argentera massif, of the Castellane and Nice arcs from $15 \mathrm{My}$ (Bulard et al., 1975; Gidon \& Pairis, 1992), and to the development of the molassic Valensole and Var basins.

The uplift of the Argentera massif has been recently investigated using apatite and zircon fission-track analysis of numerous samples collected throughout the massif. Several uplift events are recorded since 23 My and Bigot-Cormier et al. (2000) point out a recent uplift acceleration since $3.5 \mathrm{My}$ which is certainly related to tectonic process.

The present-day large-scale geomorphology is dominated by sharp relief: only 80 kilometres separate the coastline from the summits of the Argentera massif $(3000 \mathrm{~m})$. Onshore, gorges with current depth up to several hundred metres incise the topography. Offshore, there is no continental shelf, the continental slope is steep (average gradient of $11 \%$, with gradients up to $27 \%$ ) and the $2200 \mathrm{~m}$ isobath (foot of the margin) is at only 24 kilometres from the coastline. This continental slope is cut by large and deep submarine canyons, such as the Var canyon, a system which is still very active, for sediments transit, nowadays (Klaucke et al., 2000).

\section{The present-day seismicity: an alignement-type epicenters distribution}

The Côte d'Azur and the Argentera regions were periodically shaken by earthquakes of moderate magnitude (Table 1). The Ligurian earthquake (Febuary 23,1887 ), for instance, has an equivalent magnitude of 6.4 (Ferrari, 1991) and the July 19, 1963 reached 

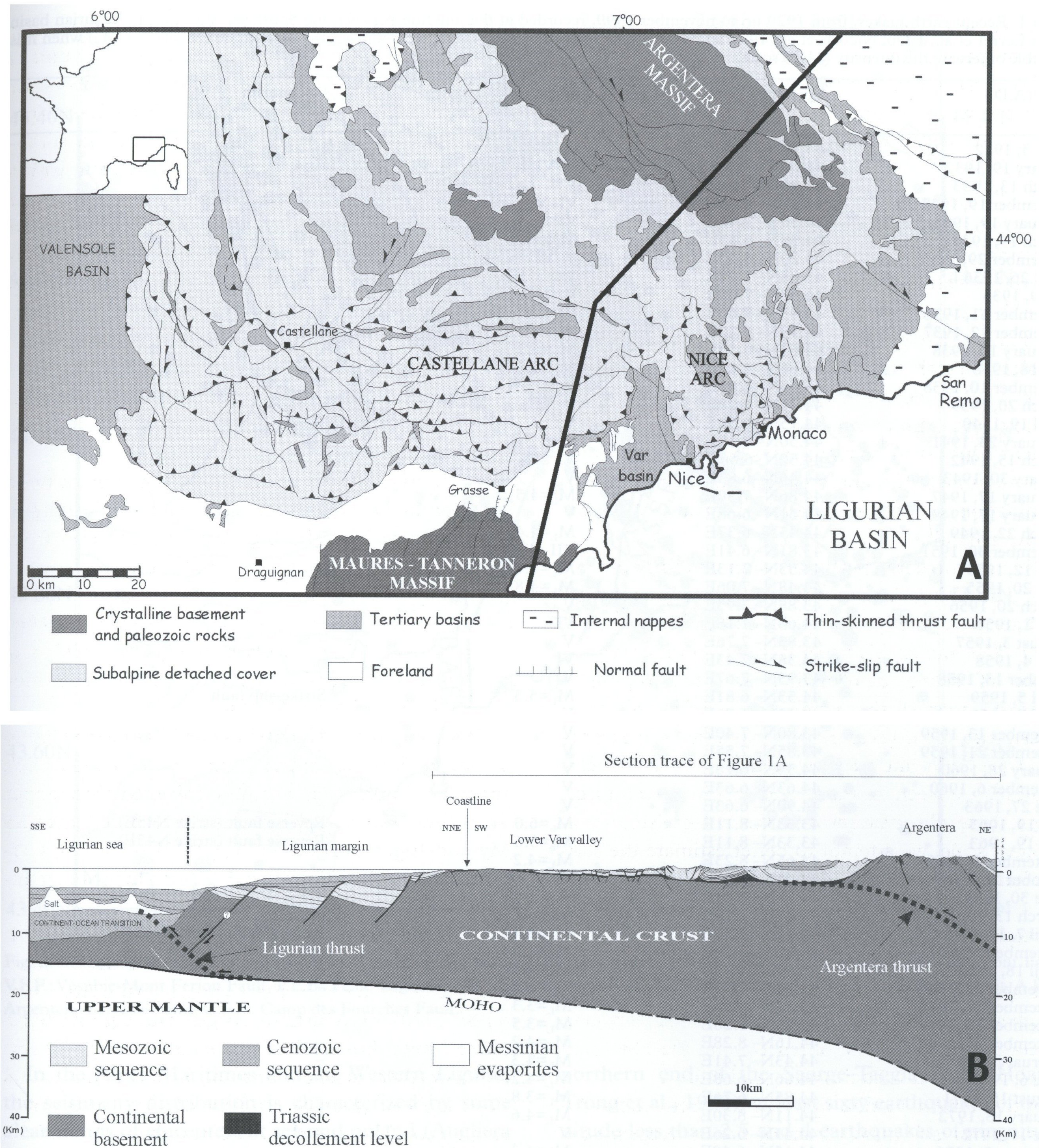

Fig. 1. (A) Structural map and (B) crustal-scale cross-section of the Southern Alps- Ligurian basin junction (modified from Laurent, 1998).

the magnitude 6.0 (Bossolasco \& Eva, 1965). The last noticable earthquake $\left(M_{L}=4.7\right)$ occured on April 21, 1995 (Courboulex et al., 1998). Finally, between 1920 and 2000, at least 76 events in the magnitude range 4.0-6.0 or intensity $\mathrm{V}$ and more (MCS scale) have occurred in this area.

The Southwestern Alps are densely covered by permanent seismological networks [ReNaSS (Réseau National de Surveillance Sismique), TGRS (Très Grande Résolution Sismique), RAP (Réseau Accélérométrique Permanent) and LDG (Laboratoire de
Détection Géophysique)]. The maximum X-Y error on the location of epicenters is around 2.5 kilometres (Nicolas et al., 1998). The seismological data collected for the last 30 years attest that earthquakes are not uniformly distributed in our area of interest (Béthoux et al., 1998). Most of the seismicity is concentrated along the northeastern side of the Argentera massif following the Pennic front and along the northern margin of the Ligurian basin (Figure 2), where the largest instrumental earthquakes have occurred (1963, $\left.M_{b}=6.0 ; 1989, M_{L}=4.5 ; 1995, M_{L}=4.7\right)$. 
Table 1. Recent earthquakes, from 1920 up to november 1999, recorded at the junction between the Southern Alps and the Ligurian basin (from Levret et al., 1996; Nicolas et al., 1998 and TGRS data base). For each event, we point out the magnitude ( $M_{L}, M_{b}$ or $M_{w}$ ) when it is available otherwise the intensity (MCS scale).

\begin{tabular}{|c|c|c|c|}
\hline Date (A.D.) & Epicenter & $\begin{array}{l}\text { Magnitude } \\
\text { or intensity }\end{array}$ & Mechanism \\
\hline April 5, 1922 & $43.78 \mathrm{~N}-6.50 \mathrm{E}$ & V & - \\
\hline January 19,1932 & $44.66 \mathrm{~N}-6.78 \mathrm{E}$ & $\mathrm{V}-\mathrm{VI}$ & - \\
\hline March 13,1933 & $44.20 \mathrm{~N}-5.95 \mathrm{E}$ & $\mathrm{V}$ & - \\
\hline September 19,1933 & $44.41 \mathrm{~N}-6.46 \mathrm{E}$ & VI-VII & - \\
\hline February 19,1935 & $44.30 \mathrm{~N}-7.40 \mathrm{E}$ & V & - \\
\hline March 19, 1935 & $44.58 \mathrm{~N}-6.63 \mathrm{E}$ & $M_{L}=4.9$ & - \\
\hline September 29,1935 & $44.20 \mathrm{~N}-6.40 \mathrm{E}$ & V-VI & - \\
\hline April 26,1936 & $43.88 \mathrm{~N}-7.45 \mathrm{E}$ & $\mathrm{V}$ & - \\
\hline July 9,1936 & $44.53 \mathrm{~N}-7.05 \mathrm{E}$ & $\mathrm{V}$ & - \\
\hline December 11,1936 & $43.93 \mathrm{~N}-7.66 \mathrm{E}$ & VI & - \\
\hline December 12,1937 & $44.93 \mathrm{~N}-6.72 \mathrm{E}$ & VI & - \\
\hline February 15,1938 & $44.61 \mathrm{~N}-6.55 \mathrm{E}$ & $\mathrm{M}_{\mathrm{L}}=4.2$ & - \\
\hline July 18,1938 & $44.66 \mathrm{~N}-6.60 \mathrm{E}$ & $M_{L}^{2}=5.1$ & - \\
\hline December 10,1938 & $44.43 \mathrm{~N}-6.43 \mathrm{E}$ & V & - \\
\hline March 20, 1939 & $44.75 \mathrm{~N}-7.28 \mathrm{E}$ & V-VI & - \\
\hline April 19, 1940 & $44.75 \mathrm{~N}-6.58 \mathrm{E}$ & V & - \\
\hline February 23,1941 & $44.50 \mathrm{~N}-7.10 \mathrm{E}$ & V & - \\
\hline March 15,1942 & $44.52 \mathrm{~N}-6.66^{\mathrm{E}}$ & V & - \\
\hline January 30, 1943 & $44.46 \mathrm{~N}-6.83 \mathrm{E}$ & V & - \\
\hline February 17,1947 & $44.86 \mathrm{~N}-7.30 \mathrm{E}$ & $M_{L}=4.5$ & - \\
\hline February 17,1949 & $44.31 \mathrm{~N}-6.68 \mathrm{E}$ & V & - \\
\hline March 22, 1949 & $44.45 \mathrm{~N}-6.37 \mathrm{E}$ & $\mathrm{M}_{\mathrm{L}}=4.4$ & - \\
\hline November 30,1951 & $43.81 \mathrm{~N}-6.41 \mathrm{E}$ & VII -VIII & - \\
\hline May 12,1955 & $44.53 \mathrm{~N}-7.13 \mathrm{E}$ & $M_{L}=4.7$ & - \\
\hline June 20,1955 & $44.48 \mathrm{~N}-7.06 \mathrm{E}$ & $\mathrm{M}_{\mathrm{L}}=4.8$ & - \\
\hline March 20, 1956 & $43.88 \mathrm{~N}-7.95 \mathrm{E}$ & $\mathrm{V}^{2}$ & - \\
\hline June 1,1956 & $44.68 \mathrm{~N}-7.18 \mathrm{E}$ & VI & - \\
\hline August 3, 1957 & $43.83 \mathrm{~N}-7.76 \mathrm{E}$ & V & - \\
\hline May 4, 1958 & $44.38 \mathrm{~N}-7.43 \mathrm{E}$ & VI & - \\
\hline October 13, 1958 & $43.93 \mathrm{~N}-7.67 \mathrm{E}$ & V & - \\
\hline April 5, 1959 & $44.53 \mathrm{~N}-6.81 \mathrm{E}$ & $M_{L}=5.3$ & Strike-slip fault \\
\hline July 17,1959 & $44.53 \mathrm{~N}-6.71 \mathrm{E}$ & $\mathrm{V}^{2}$ & - \\
\hline December 13,1959 & $43.80 \mathrm{~N}-7.40 \mathrm{E}$ & $\mathrm{V}$ & - \\
\hline December 21, 1959 & $43.85 \mathrm{~N}-7.55 \mathrm{E}$ & V & - \\
\hline January 28, 1960 & $44.55 \mathrm{~N}-6.73 \mathrm{E}$ & $\mathrm{V}$ & - \\
\hline December 6, 1960 & $44.63 \mathrm{~N}-6.63 \mathrm{E}$ & V & - \\
\hline June 27, 1963 & $44.90 \mathrm{~N}-6.63 \mathrm{E}$ & $\mathrm{V}$ & - \\
\hline July 19, 1963 & $43.33 \mathrm{~N}-8.11 \mathrm{E}$ & $M_{b}=6.0$ & Reverse fault (strike N45E) \\
\hline July 19,1963 & $43.33 \mathrm{~N}-8.11 \mathrm{E}$ & $M_{b}=5.6$ & Reverse fault (strike N45E) \\
\hline September 5, 1963 & $44.65 \mathrm{~N}-8.23 \mathrm{E}$ & $\mathrm{M}_{\mathrm{L}}=4.2$ & - \\
\hline October 22,1963 & $44.05 \mathrm{~N}-6.07 \mathrm{E}$ & $\mathrm{V}$ & - \\
\hline June 30, 1964 & $44.71 \mathrm{~N}-7.31 \mathrm{E}$ & $\mathrm{V}$ & - \\
\hline March 13, 1965 & $44.07 \mathrm{~N}-7.18 \mathrm{E}$ & $\mathrm{M}_{\mathrm{L}}=3.7$ & - \\
\hline April 7, 1966 & $44.12 \mathrm{~N}-7.39 \mathrm{E}$ & $\mathrm{M}_{\mathrm{L}}^{\mathrm{L}}=4.4$ & Reverse fault (strike N120E) \\
\hline December 6, 1967 & $44.00 \mathrm{~N}-7.23 \mathrm{E}$ & $\mathrm{M}_{\mathrm{L}}=3.2$ & - \\
\hline April 18, 1968 & $43.95 \mathrm{~N}-8.13 \mathrm{E}$ & $\mathrm{M}_{\mathrm{L}}=4.5$ & - \\
\hline November 22, 1969 & $44.38 \mathrm{~N}-6.63 \mathrm{E}$ & $M_{L}^{2}=3.6$ & - \\
\hline December 29, 1970 & $44.23 \mathrm{~N}-8.25 \mathrm{E}$ & $M_{L}^{L}=3.3$ & - \\
\hline December 30,1970 & $44.20 \mathrm{~N}-8.28 \mathrm{E}$ & $M_{L}^{2}=3.5$ & - \\
\hline December 31, 1970 & $44.16 \mathrm{~N}-8.28 \mathrm{E}$ & $\mathrm{M}_{\mathrm{L}}=4.2$ & - \\
\hline February 1,1971 & $44.43 \mathrm{~N}-7.41 \mathrm{E}$ & $\mathrm{M}_{\mathrm{L}}=4.3$ & - \\
\hline June 6,1971 & $44.66 \mathrm{~N}-6.68 \mathrm{E}$ & $\mathrm{M}_{\mathrm{L}}=4.2$ & - \\
\hline August 15, 1971 & $44.85 \mathrm{~N}-6.76 \mathrm{E}$ & $\mathrm{M}_{\mathrm{L}}=3.8$ & - \\
\hline January 18, 1972 & $44.11 \mathrm{~N}-8.30 \mathrm{E}$ & $M_{L}^{2}=4.6$ & - \\
\hline June 19,1972 & $44.41 \mathrm{~N}-6.26 \mathrm{E}$ & $\mathrm{V}^{2}$ & - \\
\hline February 8,1974 & $44.15 \mathrm{~N}-6.48 \mathrm{E}$ & $M_{L}=4.3$ & - \\
\hline August 7, 1974 & $44.43 \mathrm{~N}-6.38 \mathrm{E}$ & $M_{L}=3.1$ & - \\
\hline February 6, 1977 & $44.49 \mathrm{~N}-7.34 \mathrm{E}$ & $\mathrm{M}_{\mathrm{L}}=4.0$ & Reverse fault (strike N110E) \\
\hline March 3, 1977 & $44.69 \mathrm{~N}-6.69 \mathrm{E}$ & $\mathrm{M}_{\mathrm{L}}=4.0$ & Normal fault (strike N160E) \\
\hline January 5, 1980 & $44.98 \mathrm{~N}-7.47 \mathrm{E}$ & $\mathrm{M}_{\mathrm{L}}=5.3$ & - \\
\hline October 10,1980 & $44.45 \mathrm{~N}-7.15 \mathrm{E}$ & $\mathrm{M}_{\mathrm{L}}=4.3$ & - \\
\hline April 22, 1981 & $43.31 \mathrm{~N}-8.23 \mathrm{E}$ & $M_{L}^{2}=4,5$ & Strike-slip fault \\
\hline March 20, 1983 & $44.34 \mathrm{~N}-6.48 \mathrm{E}$ & $\mathrm{M}_{\mathrm{L}}^{\mathrm{L}}=4.1$ & - \\
\hline June 19,1984 & $44.05 \mathrm{~N}-6.15 \mathrm{E}$ & $\mathrm{M}_{\mathrm{L}}=4.3$ & - \\
\hline June 30,1984 & $44.05 \mathrm{~N}-6.13 \mathrm{E}$ & $M_{L}^{L}=4.1$ & - \\
\hline October 4, 1985 & $43.63 \mathrm{~N}-8.09 \mathrm{E}$ & $M_{L}^{2}=4,1$ & Reverse fault (strike N35E) \\
\hline May 1, 1986 & $43.43 \mathrm{~N}-7.45 \mathrm{E}$ & $M_{L}^{2}=3.9$ & Left-lateral fault (strike N150E) \\
\hline December 26, 1989 & $43.54 \mathrm{~N}-7.54 \mathrm{E}$ & $M_{L}=4,5$ & Reverse fault (strike N50E) \\
\hline April 15, 1990 & $43.58 \mathrm{~N}-7.81 \mathrm{E}$ & $M_{L}=4,3$ & Strike slip fault \\
\hline April 21, 1995 & $43.46 \mathrm{~N}-7.34 \mathrm{E}$ & $\mathrm{M}_{\mathrm{L}}^{\mathrm{L}}=4,7$ & Dextral reverse fault (strike N100E) \\
\hline February 24, 1997 & $43.70 \mathrm{~N}-8.50 \mathrm{E}$ & $M_{L}=4.1$ & - \\
\hline June 26,1997 & $43.90 \mathrm{~N}-7.20 \mathrm{E}$ & $M_{L}=3,8$ & - \\
\hline October 10,1997 & $42.20 \mathrm{~N}-6.60 \mathrm{E}$ & $M_{L}=4.5$ & - \\
\hline November 11, 1997 & $44.10 \mathrm{~N}-7.90 \mathrm{E}$ & $\mathrm{M}_{\mathrm{L}}=4.0$ & - \\
\hline July 7,1999 & $44.64 \mathrm{~N}-6.81 \mathrm{E}$ & $M_{L}=3.9$ & - \\
\hline November 1, 1999 & $43.80 \mathrm{~N}-7.30 \mathrm{E}$ & $M_{\mathrm{w}}^{2}=3,4$ & Left-lateral fault (strike N45E) \\
\hline
\end{tabular}




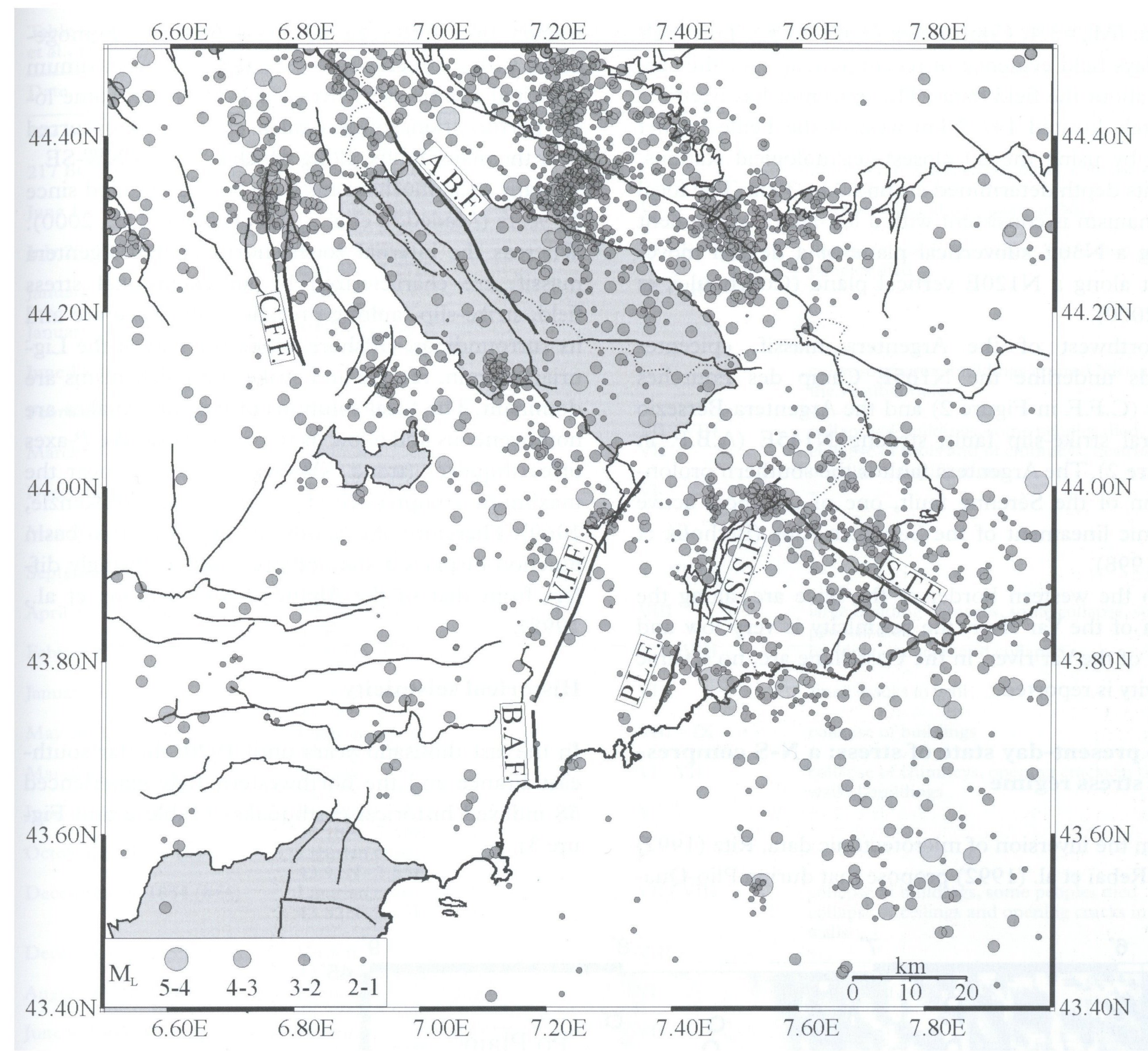

Fig. 2. Instrumental seismicity from 1980 to 1999 (modified from BCSF) and major onshore faults, B.A.F.: Saint Blaise-Aspremont Fault, V.F.F.: Vésubie-Mont Férion Fault, P.L.F.: Peille-Laghet Fault, M.S.S.F.: Monaco-Sospel-Saorge Fault, S.T.F.: Saorge-Taggia Fault, A.B.F.: Argentera-Bersezio Fault, C.F.F.: Camp des Fourches Fault.

In the Alpes Maritimes and the Western Liguria, the seismicity distribution is characterized by some clear trends of epicenters at sea and onland (Augliera et al, 1994). In some places, there is a correlation between the seismic lineaments and some of the faults that have been recognized in the field. Particularly, we observe:

An alignement of epicenters which corresponds to the dextral strike-slip fault which runs between Saorge and Taggia (S.T.F. in Figure 2) and the parallel faults, trending N120E (Hoang-Trong et al., 1987; Augliera et al, 1994; Eva et al., 2000). This fault system was recently the location of some small earthquakes (Béthoux et al., 1992), e.g. December 4, 1983 $\left(M_{L}=3.5\right)$ and October 20, $1986\left(M_{L}=3.0\right)$. During the last quarter of 1983, a seismic swarm occured along the valley of the middle Roya river, at the northern end of the Saorge-Taggia fault (HoangTrong et al., 1983): at least sixty earthquakes of magnitude less than 2.5 and 4 earthquakes of magnitude around 3 have been recorded. The multiple event mechanism and the N110E linear trend of the swarm indicate a major role of the Saorge-Taggia fault during this seismic swarm.

The conjugate direction $\mathrm{N} 30 \mathrm{E}$ is recognized in the field as the Monaco-Sospel-Saorge (M.S.S.F. in Figure 2). In the northeastern prolongation of this fault, we observe an alignement of epicenters along the $\mathrm{N} 30 \mathrm{E}$ direction which allow to propose the continuation of the Monaco-Sospel-Saorge fault at depth in the N-E direction until several tens of kilometres.

Thirty kilometres east of Nice, a segment of the N20E left-lateral Peille-Laghet fault (P.L.F. in Figure 2) probably produced the November, $1^{\text {st }} 1999$ earth- 
quake $\left(M_{W}=3.4\right.$, Courboulex et al., 2000). This fault displays field evidence of recent activity (see the section about the field data). The epicenter has been accurately located $1+/-2 \mathrm{~km}$ west of the Peille-Laghet fault by using the 20 closest seismological stations, and its depth determined around $2+/-3 \mathrm{~km}$. The focal mechanism is consistent with a left-lateral movement along a N30E subvertical plane or a dextral movement along a N120E vertical plane (Courboulex et al., 2000).

Northwest of the Argentera massif, epicenter trends underline the N165E Camp des Fourches fault (C.F.F. in Figure 2) and the Argentera-Bersezio dextral strike-slip fault, striking N145E (A.B.F. in Figure 2). The Argentera fault is the southern prolongation of the Sérenne fault, one of the most active seismic lineament of the Southern Alps (Béthoux et al., 1998).

To the western border of the Nice arc, along the delta of the Var river, the seismicity is very low and west of the Var river, in the Castellane arc, no seismic activity is reported.

\section{The present-day state of stress: a N-S compres- sive stress regime}

From the inversion of microtectonic data, Ritz (1992) and Rebaï et al. (1992) propose that during Plio-Qua- ternary time, the regional stress field was homogenous, with a roughly $\mathrm{N}-\mathrm{S}$ direction of the maximum principal compressive stress $\left(\sigma_{1}\right)$. However, some local perturbations of this main stress field occurred near the major faults, along which $\sigma_{1}$ trends NW-SE.

Many focal mechanisms have been computed since 30 years (Madeddu et al., 1996; Baroux et al., 2000). Whereas the internal zones, north of the Argentera massif, are characterized by an extensional stress field, strike-slip faulting prevails at the Nice arc and its surroundings. Offshore, along the foot of the Ligurian margin, reverse and strike-slip mechanisms are dominant. The focal solutions of the earthquakes are homogeneous and allow us to propose that the $P$-axes of earthquakes (trend NW-SE to N-S) are near the maximum compressive stress direction (McKenzie, 1969). Therefore, the Southern Alps- Ligurian basin junction displays a state of stress which strongly differs from that of the Alpine chain (Béthoux et al., 1998).

\section{Historical seismicity}

In the last thousand years until 1920, the far southeast France and the northwestern Italy experienced 58 indexed historical earthquakes (Table 2 and Figure 3).

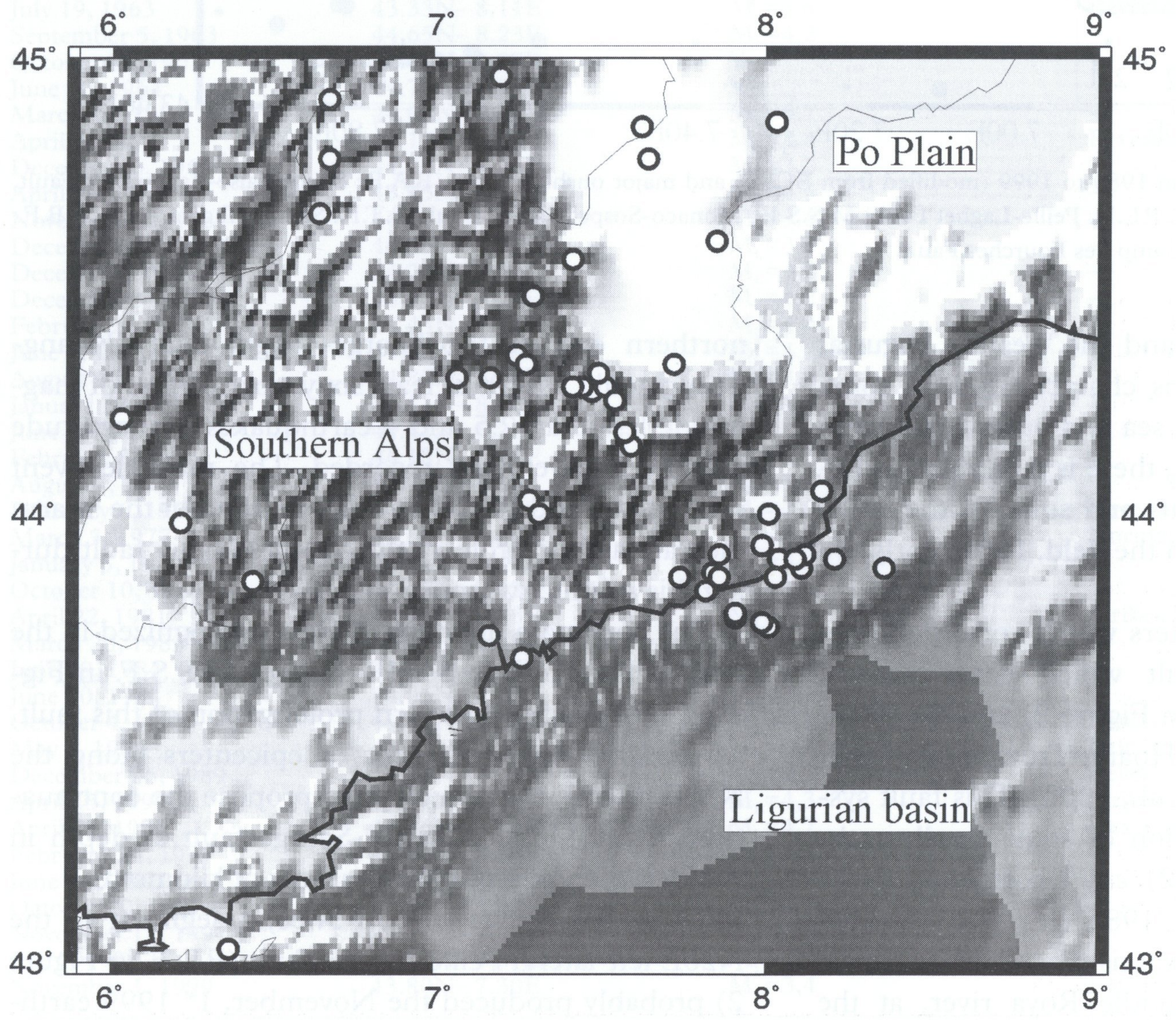

Fig. 3. Historical seismicity: white dots are macroseismic locations of epicenters for the events with an intensity higher than $\mathrm{V}$ (see Table 2 for data). 
Table 2. Some characteristics of historical earthquakes until 1920. Data are from Boschi et al., 1995 ( ${ }^{*}$; Lambert \& Levret, 1996 (\#); Boschi et al., 1997 (€) and Laurenti, $1998(\S)$.

\begin{tabular}{|c|c|c|c|}
\hline Date & Location & Intensity & Effects \\
\hline $322 \mathrm{BC}\left({ }^{\star} €\right)$ & $\begin{array}{l}\text { Western Liguria } \\
44.00 \mathrm{~N}-8.00 \mathrm{E}\end{array}$ & - & - \\
\hline $217 \mathrm{BC}\left({ }^{\star} €\right)$ & $\begin{array}{l}\text { Western Liguria } \\
44.00 \mathrm{~N}-8.00 \mathrm{E}\end{array}$ & - & $\begin{array}{l}\text { destruction of numerous cities, collapse of } \\
\text { mountain, offsets of river }\end{array}$ \\
\hline June 13, $1494\left({ }^{\star} \# € \S\right)$ & $\begin{array}{l}\text { Vésubie valley } \\
43.68 \mathrm{~N}-7.25 \mathrm{E}\end{array}$ & VI & collapse of buildings, panic in Nice \\
\hline July $20,1564\left({ }^{\star} \# € \S\right)$ & $\begin{array}{l}\text { Roquebilière } \\
44.03 \mathrm{~N}-7.27 \mathrm{E}\end{array}$ & $\mathrm{IX}-\mathrm{X}$ & $\begin{array}{l}\text { destruction of Roquebilière, more than } 300 \\
\text { peoples died }\end{array}$ \\
\hline $\begin{array}{l}\text { January } 31,1612(\#) \\
\text { Iune } 30,1612(\Phi)\end{array}$ & $\begin{array}{l}\text { Liguria } \\
\text { Near Nice }\end{array}$ & VI - VII & $\begin{array}{l}- \\
-\end{array}$ \\
\hline January $18,1618(\#)$ & $\begin{array}{l}\text { Vésubie valley } \\
43.88 \mathrm{~N}-7.28 \mathrm{E} \text { VIII- }\end{array}$ & & \\
\hline June $14-16,1618(\$)$ & Near Nice & - & $\begin{array}{l}\text { collapse of some buildings around Nice and in } \\
\text { the Vésubie valley }\end{array}$ \\
\hline February $15,1644\left({ }^{\star} \# € \rrbracket\right)$ & $\begin{array}{l}\text { Vésubie valley } \\
44.00 \mathrm{~N}-7.30 \mathrm{E}\end{array}$ & VII - VIII & collapse of buildings, some peoples died \\
\hline March 9, 1753 (\#€) & $\begin{array}{l}\text { Piedmont } \\
44.93 \mathrm{~N}-7.18 \mathrm{E}\end{array}$ & VII & $\begin{array}{l}\text { collapse of roofs and of chimneys, destruction } \\
\text { of military fortifications }\end{array}$ \\
\hline December 31, 1773 (\#) & $\begin{array}{l}\text { Queyras } \\
44.66 \mathrm{~N}-6.63 \mathrm{E}\end{array}$ & VI & - \\
\hline March 31, $1806(\#)$ & $\begin{array}{l}\text { Liguria } \\
44.85 \mathrm{~N}-7.61 \mathrm{E}\end{array}$ & $\mathrm{V}-\mathrm{VI}$ & - \\
\hline September 5, 1807 (\#) & $\begin{array}{l}\text { Liguria } \\
44.78 \mathrm{~N}-7.63 \mathrm{E}\end{array}$ & $\mathrm{V}-\mathrm{VI}$ & 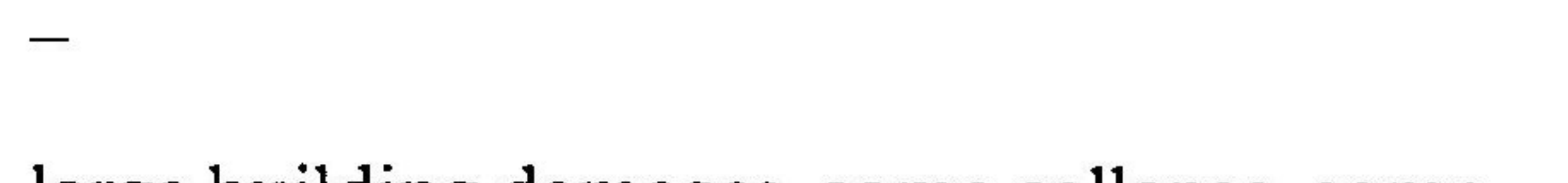 \\
\hline April 2, $1808\left({ }^{\star} \# €\right)$ & $\begin{array}{l}\text { Pellice valley } \\
44.83 \mathrm{~N}-7.27 \mathrm{E}\end{array}$ & VIII & $\begin{array}{l}\text { large building damages, some collapse, some } \\
\text { peoples died }\end{array}$ \\
\hline February 23, $1818(\# € \S)$ & $\begin{array}{l}\text { Ligurian coast } \\
43.82 \mathrm{~N}-7.65 \mathrm{E}\end{array}$ & VII - VIII & building damages and collapse \\
\hline January 8, 1819 (\#€) & $\begin{array}{l}\text { Ligurian coast } \\
44.05 \mathrm{~N}-8.20 \mathrm{E}\end{array}$ & VI & small cracks in wall \\
\hline May $26,1831\left({ }^{\star} \# € \S\right)$ & $\begin{array}{l}\text { Ligurian coast } \\
43.85 \mathrm{~N}-7.85 \mathrm{E}\end{array}$ & VIII - IX & collapse of buildings \\
\hline March $23,1835(€)$ & $\begin{array}{l}\text { Liguria } \\
44.33 \mathrm{~N}-7.55 \mathrm{E}\end{array}$ & VI - VII & $\begin{array}{l}\text { collapse of chimneys, opening cracks in the } \\
\text { wall of buildings }\end{array}$ \\
\hline October 13, $1851(\#)$ & $\begin{array}{l}44.18 \mathrm{~N}-7.56 \mathrm{E} \\
\text { Ligurian coast }\end{array}$ & r & 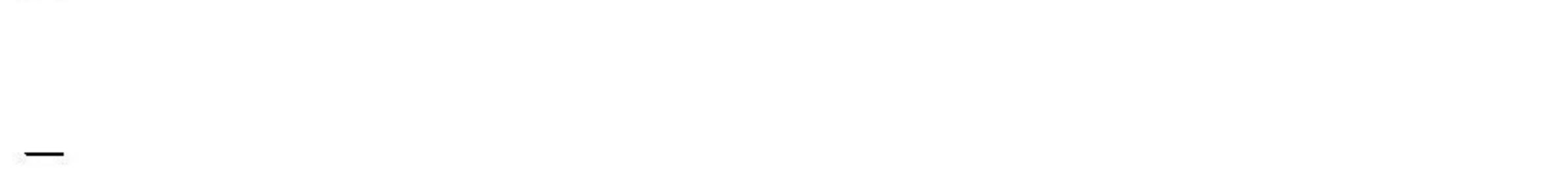 \\
\hline December $29,1854(\# € \mathbb{\Omega})$ & $\begin{array}{l}\text { Ligurian coast } \\
43.91 \mathrm{~N}-7.85 \mathrm{E} \\
\text { Ligurian coast }\end{array}$ & VII - VIUI & collanse of buildings. some neonles died \\
\hline December 29,1854 (\#૯\) & $\begin{array}{l}\text { Ligurian coast } \\
43.82 \mathrm{~N}-7.55 \mathrm{E}\end{array}$ & & $\begin{array}{l}\text { collapse of ceilings and opening cracks in the } \\
\text { walls }\end{array}$ \\
\hline December $12,1855(\#)$ & $\begin{array}{l}\text { Verdon } \\
43.85 \mathrm{~N}-6.43 \mathrm{E}\end{array}$ & VIII & - \\
\hline August $30,1858(\# €)$ & $\begin{array}{l}\text { Piemont } \\
44.32 \mathrm{~N}-7.33 \mathrm{E}\end{array}$ & VI & collapse of roofs \\
\hline June 9,1863 (\#) & Barrème $43.98 \mathrm{~N}-6.21 \mathrm{E}$ & VII & 1 \\
\hline May 19, $1866(\#)$ & $\begin{array}{l}\text { La Motte du Caire } \\
44.21 \mathrm{~N}-6.03 \mathrm{E}\end{array}$ & VII -VIII & large building damages \\
\hline January 22, 1878 (\#) & $\begin{array}{l}\text { Piedmont } \\
44.60 \mathrm{~N}-7.48 \mathrm{E}\end{array}$ & $\mathrm{V}-\mathrm{VI}$ & - \\
\hline June 7, 1878 (\#) & $\begin{array}{l}\text { Piedmont } \\
44.48 \mathrm{~N}-7.28 \mathrm{E}\end{array}$ & VII & ononing crocles collonce of chimnourc \\
\hline November 27, 1884 (\#€) & $\begin{array}{l}\text { Queyras } \\
44.78 \mathrm{~N}-6.66 \mathrm{E}\end{array}$ & VII & $\begin{array}{l}\text { opening cracks, collapse of chimneys, } \\
\text { collapse of small buildings }\end{array}$ \\
\hline fuly 1,1885 (\#) & $\begin{array}{l}\text { Piedmont } \\
44.25 \mathrm{~N}-7.53 \mathrm{E}\end{array}$ & $V-V 1$ & " \\
\hline February $23,1887\left({ }^{\star} \# € \rrbracket\right)$ & $\begin{array}{l}\text { Ligurian coast } \\
43.88 \mathrm{~N}-8.00 \mathrm{E}\end{array}$ & $\mathrm{X}$ & $\begin{array}{l}\text { collapse of mountain, destruction of numerous } \\
\text { cities along the Riviera, tsunami waves, more } \\
\text { than } 600 \text { peoples died }\end{array}$ \\
\hline August $18,1888(\#)$ & $\begin{array}{l}\text { Ligurian coast } \\
43.90 \mathrm{~N}-8.08 \mathrm{E}\end{array}$ & V & - \\
\hline September 16,1890 (\#) & $\begin{array}{l}\text { Ligurian coast } \\
43.86 \mathrm{~N}-8.02 \mathrm{E}\end{array}$ & $\mathrm{V}$ & - \\
\hline May 8, $1892(\#)$ & $\begin{array}{l}\text { Taggia } \\
43.78 \mathrm{~N}-7.90 \mathrm{E}\end{array}$ & $\mathrm{V}$ & - \\
\hline November 26, $1892(\#)$ & $\begin{array}{l}\text { Limone Piemonte } \\
44.27 \mathrm{~N}-7.46 \mathrm{E}\end{array}$ & V & - \\
\hline November 27, $1892(\#)$ & $\begin{array}{l}\text { Limone Piemonte } \\
44.28 \mathrm{~N}-7.50 \mathrm{E}\end{array}$ & V & - \\
\hline anuary $2,1893(\#)$ & $\begin{array}{l}\text { Piedmont } \\
44.30 \mathrm{~N}-7.15 \mathrm{E}\end{array}$ & $\mathrm{V}-\mathrm{VI}$ & - \\
\hline April 6, 1894 (\#) & $\begin{array}{l}\text { Piedmont } \\
44.28 \mathrm{~N}-7.43 \mathrm{E}\end{array}$ & $\mathrm{V}$ & - \\
\hline uly $19,1894(\#)$ & $\begin{array}{l}\text { Taggia } \\
43.83 \mathrm{~N}-7.81 \mathrm{E}\end{array}$ & $\mathrm{V}$ & - \\
\hline February 3, 1895 (\#) & $\begin{array}{l}\text { Liguria } \\
43.90 \mathrm{~N}-8.20 \mathrm{E}\end{array}$ & $\mathrm{V}$ & - \\
\hline
\end{tabular}


Table 2. Contineous.

\begin{tabular}{|c|c|c|c|}
\hline Date & Location & Intensity & Effects \\
\hline March 18, 1895 (\#) & $\begin{array}{l}\text { Piedmont } \\
44.28 \mathrm{~N}-7.40 \mathrm{E}\end{array}$ & $\mathrm{V}$ & - \\
\hline December 25, $1895(\#)$ & $\begin{array}{l}\text { Liguria } \\
43.88 \mathrm{~N}-8.35 \mathrm{E}\end{array}$ & $\mathrm{V}$ & - \\
\hline October 16, 1896 (\#) & $\begin{array}{l}\text { Liguria } \\
43.76 \mathrm{~N}-7.98 \mathrm{E}\end{array}$ & VII & - \\
\hline October 12,1897 & Imperia & V & - \\
\hline December 26, 1899 (\#) & $\begin{array}{l}\text { Cuneo } \\
44.34 \mathrm{~N}-7.24 \mathrm{E}\end{array}$ & $\mathrm{V}$ & - \\
\hline April 5, $1900(\#)$ & $\begin{array}{l}\text { Cuneo } \\
44.56 \mathrm{~N}-7.40 \mathrm{E}\end{array}$ & V & - \\
\hline May $1900,10(\#)$ & $\begin{array}{l}\text { Cuneo } \\
44.30 \mathrm{~N}-7.05 \mathrm{E}\end{array}$ & $\mathrm{V}-\mathrm{VI}$ & - \\
\hline April 20, $1901(\#)$ & $\begin{array}{l}\text { Cuneo } \\
44.31 \mathrm{~N}-7.48 \mathrm{E}\end{array}$ & VI & - \\
\hline April 4, $1903(\#)$ & $\begin{array}{l}\text { Liguria } \\
43.88 \mathrm{~N}-8.10 \mathrm{E}\end{array}$ & $\mathrm{V}-\mathrm{VI}$ & anoming onolo in tho woll of militomu huld dinm \\
\hline July 12, 1904 (\#€) & $\begin{array}{l}\text { Briançon } \\
44.93 \mathrm{~N}-6.85 \mathrm{E}\end{array}$ & VII & $\begin{array}{l}\text { opening craks in the wall of military buildings, } \\
\text { collapse of chimneys }\end{array}$ \\
\hline November 15, 1904 (\#) & $\begin{array}{l}\text { Taggia } \\
43.86 \mathrm{~N}-7.73 \mathrm{E}\end{array}$ & $\mathrm{V}$ & - \\
\hline May 30, $1905(\#)$ & $\begin{array}{l}\text { Piemont } \\
44.33 \mathrm{~N}-7.71 \mathrm{E}\end{array}$ & VI & 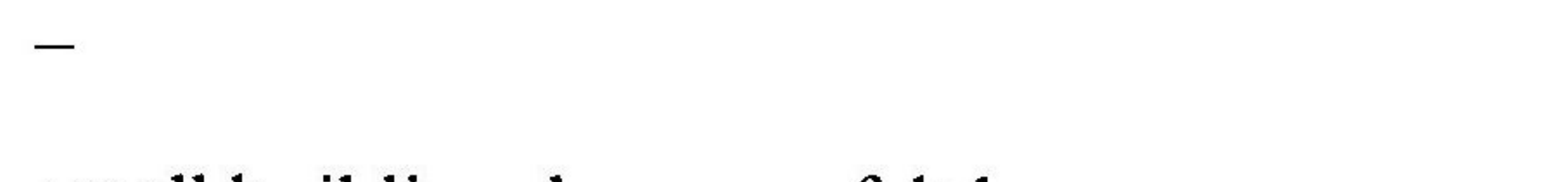 \\
\hline August 11, $1906(\#)$ & $\begin{array}{l}\text { Taggia } \\
43.86 \mathrm{~N}-7.85 \mathrm{E}\end{array}$ & VI & $\begin{array}{l}\text { small building damages, felt by numerous } \\
\text { people }\end{array}$ \\
\hline May 27, 1909 (\#) & $\begin{array}{l}\text { Liguria } \\
43.91 \mathrm{~N}-8.11 \mathrm{E}\end{array}$ & VI & felt by numerous people \\
\hline October 5, 1909 (\#) & $\begin{array}{l}\text { Piemont } \\
44.73 \mathrm{~N}-7.15 \mathrm{E}\end{array}$ & V & - \\
\hline $\begin{array}{l}\text { September } 27,1911(\#) \\
\text { July } 24,1913(\#)\end{array}$ & $\begin{array}{l}\text { Barrême } \\
44.03 \mathrm{~N}-6.36 \mathrm{E} \\
\text { Piedmont } \\
44.35 \mathrm{~N}-7.23 \mathrm{E}\end{array}$ & $\begin{array}{l}\text { V } \\
\text { V }\end{array}$ & - \\
\hline May 1, $1917(\#)$ & $\begin{array}{l}\text { Liguria } \\
44.05 \mathrm{~N}-8.16 \mathrm{E}\end{array}$ & $\mathrm{V}$ & - \\
\hline November 28, 1919 (\#) & $\begin{array}{l}\text { Piedmont } \\
44.15 \mathrm{~N}-7.58 \mathrm{E}\end{array}$ & $\mathrm{V}-\mathrm{VI}$ & - \\
\hline
\end{tabular}

At least two of these earthquakes caused serious regional casualities: the Roquebilière earthquake (1564) and the Ligurian earthquake (1887), that reached an intensity of X MCS (Boschi et al., 1995; Lambert \& Levret, 1996; Boschi et al., 1997; Laurenti, 1998; Working Group CPTI, 1999). The Ligurian earthquake produced tsunami waves observed along $250 \mathrm{~km}$ of the Ligurian coast from Genoa to Cannes, with run-up heights around 1-2 m (Eva \& Rabinovitch, 1997).

The location of these historical epicenters is not accurate enough for them to be attributed to known active faults. Nevertheless, the Argentera-Bersezio fault is proposed to be the locus of the July 18, 1938 and for the April 5, 1959 earthquakes (Ghafiri, 1995). The historical data show that three regions encompass more than half of the events registered: the Vésubie valley, the Ligurian coast and the Piedmont. The Vésubie-Mt Férion fault (V.F.F. in Figure 2) may have been the location of the 5 earthquakes that strongly shook this valley. But most events felt along the Ligurian coast have offshore epicenters and are therefore related to unidentified faults. The historical data set also indicates that no earthquakes have been reported west of the Var river, in the Castellane arc.

\section{Geodetic measurements: a N-S shortening about $2-4 \mathrm{~mm} / \mathbf{y r}$}

Because of low expected strain rates, close to the accuracy of the geodetic techniques, direct measurements of crustal strain in the southern French Alps are challenging and must use strategies specifically designed for detecting very low tectonic signals. One possibility is to use old triangulation (or trilateration) measurements. A GPS field experiment has been performed in 1998: we combined first- and second-order triangulation data, collected in 1948 by the French "Institut Géographique National», with GPS data collected at 14 of these IGN sites. The network covers the southern part of the Argentera massif, the Castellane arc, down to the mediterranean coastline (Figure 4).

From the combination of the GPS and triangulation data, Calais et al. (2000) obtained the direction of the maximum compressive principal strain rate (geodetic unit of deformation), that correspond to "P-axis» in the seismological nomenclature.

The results show that a deformation significantly different from zero affected most of the network during a period of 50 years. The maximum compressive 


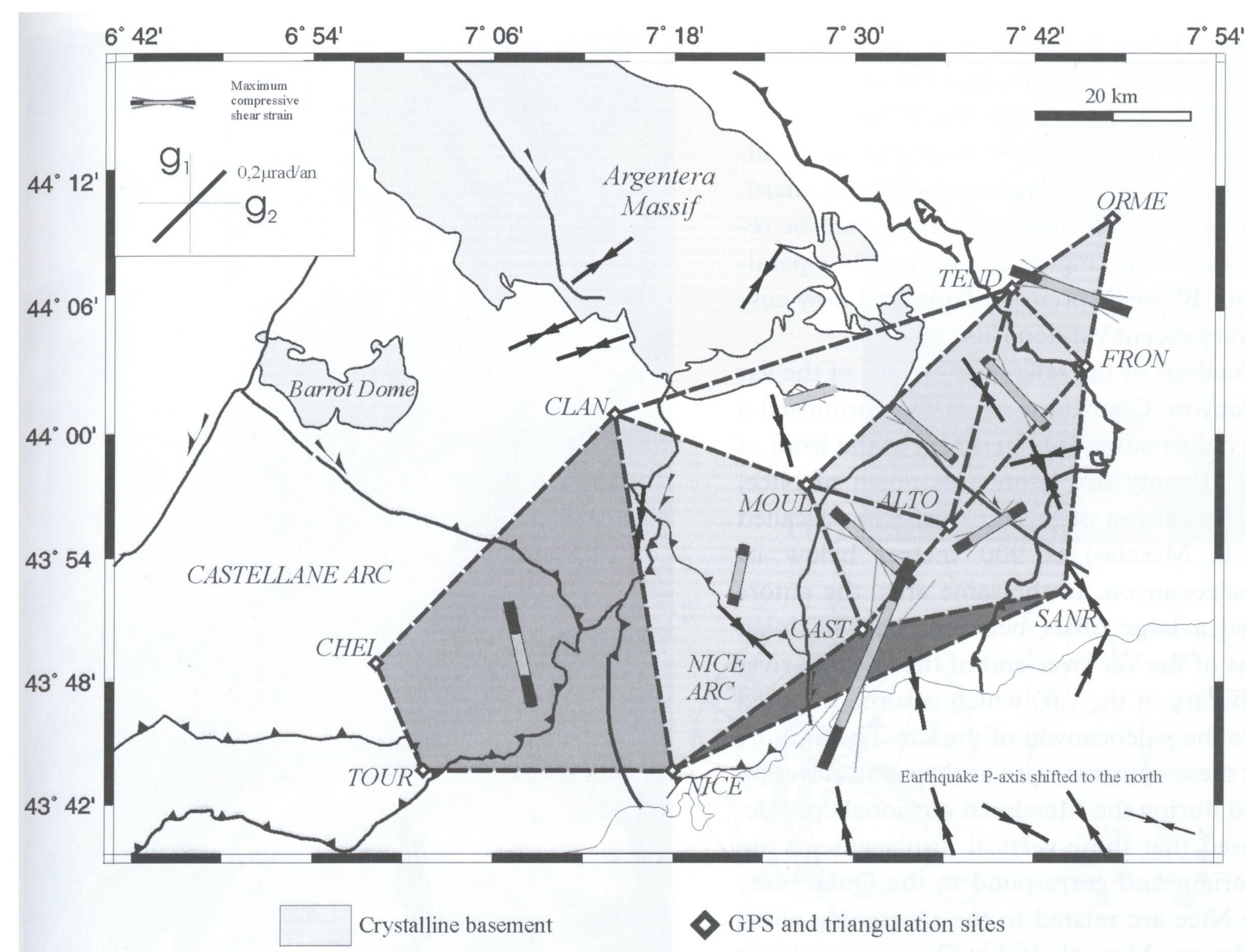

Fig. 4. Geodetic deformation map over 50 years showing the final shear strain rate solution obtained from the combination of triangulation and GPS data. The spatial distribution of the shear strain rate displays 3 domains with homogeneous behaviour. (1) N-S compression in the western half of the network (grey area), (2) NE-SW compression in the southern part (strong grey area) and (3) NW-SE compression in the remaining part of the network (ligth grey area). The black arrows show P-axis of earthquakes (modified from Calais et al., 2000).

shear strain rate is in the order of $0.1-0.2 \mu \mathrm{rad} / \mathrm{yr}$ over distance in the order of $30 \mathrm{~km}$. The spatial distribution of the shear strain rate displays 3 domains with homogeneous behaviour: N-S compression in the western half of the network, NE-SW compression in the southern part and NW-SE compression in the remaining of the network (Figure 4). The NE-SW direction obtained in the coastal area is considered as an artefact related to the very elongated shape of this triangle (Calais et al., 2000). The N-S to NW-SE compression is in agreement with the seismological ( $P$-axes strikes of earthquakes) and the microtectonic data that both are consistent with a N-S to NW-SE compressive strain and stress in the Southern Alps during the Quaternary. Assuming a rate of 0.1-0.2 $\mu \mathrm{rad} / \mathrm{yr}$, the N-S shortening over the whole network is in the order of $2-4 \mathrm{~mm} / \mathrm{yr}$ (Calais et al., 2000).

\section{Field evidence of active and recent deformation}

Evidence of active and recent deformation has been reported in the Alpes Maritimes:

Marine Pliocene sediments that disconformably over- lie the western edge of the Nice arc along the left bank of the Var river have been locally folded and faulted (including the Nice city area itself). Thirty kilometres north of Nice, remnants of these sediments have been uplifted as high as $1100 \mathrm{~m}$ (Irr, 1984; Clauzon et al., 1996; Fauquette et al., 1999). Pliocene and Quaternary sediments have been clearly more uplifted and deformed on the eastern side of the Var river than on the western side (Dubar \& Perez, 1989; Schroetter, 1998). These differential movements, from both sides of the lower Var valley, are probably related to the recent thin-skin southward thrusting of the Nice arc and more accurately to the recent activity of the so-called 'Vésubie-Mont Férion' (V.F.F. in Figure 2) and 'Saint Blaise-Aspremont' (B.A.F. in Figure 2) fault system. Furthermore, this inherited N-S fault zone show radon anomalies interpreted by Borchielini et al. (1991) as an evidence for tectonic activity.

On both side of the Var river mouth, the identification and the datation of late Pliocene and Quaternary terraces allow to quantify the relative differential uplift between the eastern and western sides of the river 
near the coast. Dubar \& Gugliemi (1996) found an altitudinal offset of $50 \mathrm{~m}$ for a late Pliocene terrace (2-1.67 My). They proposed that this differential uplift velocity is about $0.025-0.05 \mathrm{~mm} / \mathrm{yr}$ with an acceleration during the recent Quaternary (Tyrrhenian). The tectonic origin of this vertical offset could be related to a hidden fault (Figure 2), more or less parallel to the Saint Blaise-Aspremont fault, and now covered by the very recent Var deposits.

From an analysis of the reference surface of the Var Messinian canyon, Clauzon et al. (1996) proposed a more recent deformation (Quaternary) at the front of the Nice arc. Twenty five kilometres north of Nice, the present-day canyon of the Var river (the so-called "gorges de la Mescla») is 900 metres below its Messinian paleocanyon. In the same area, the autors also observed a large offset between the Messinian paleocanyons of the Var river and of the Vésubie river (a major tributary of the Var) which is some hundred metres above the paleocanyon of the Var. The authors assume that these canyons were at the same elevation when formed during the Messinian erosional episode. They proposed that these vertical displacements are of tectonic origin and correspond to the Quaternary uplift of the Nice arc related to the shortening along the frontal thrusts. Nevertheless, a Quaternary thrust at the southwestern boundary of the Nice arc has not yet been identified.

The endokarst, where vegetation is absent and erosion is reduced, is a very well protective place to observe and measure tiny movements (Gilli, 1981). In the grotte of 'Les Deux Gourdes', near the VésubieMont Férion fault (V.F.F. in Figure 2), Gilli (1986) observed a Holocene concretioning on the fault plane: stalactites, stalagmites and flowstones. Lengthwise fractured pillar, displaced stalactite/stalagmite and folding of the stalagmitic flowstones are interpreted as the result of at least 2 episodes of movement along the fault plane with a total amplitude of $10 \mathrm{~cm}$ (Figure 5). In the Castellane arc, Gilli \& Delange (1999) found evidence for very recent (some tens of thousand years ?) southward thrusting from offsets in speleothems built in karstic galleries along the northdipping frontal thrust. Similar evidence is observed along the Calern thrust (north of Grasse, Figure 1) where a study is in progress using a micrometric sensor in order to quantify the assumed present-day displacement.

Plio-Pleistocene sediments have been deformed along the left-lateral N20E Peille-Laghet fault (P.L.F. in Figure 2): a network of striated fault planes crosscut Plio-Quaternary breccia with N-S to NE-SW directions (Figure 6).

The inversion of the microtectonic data leads to a

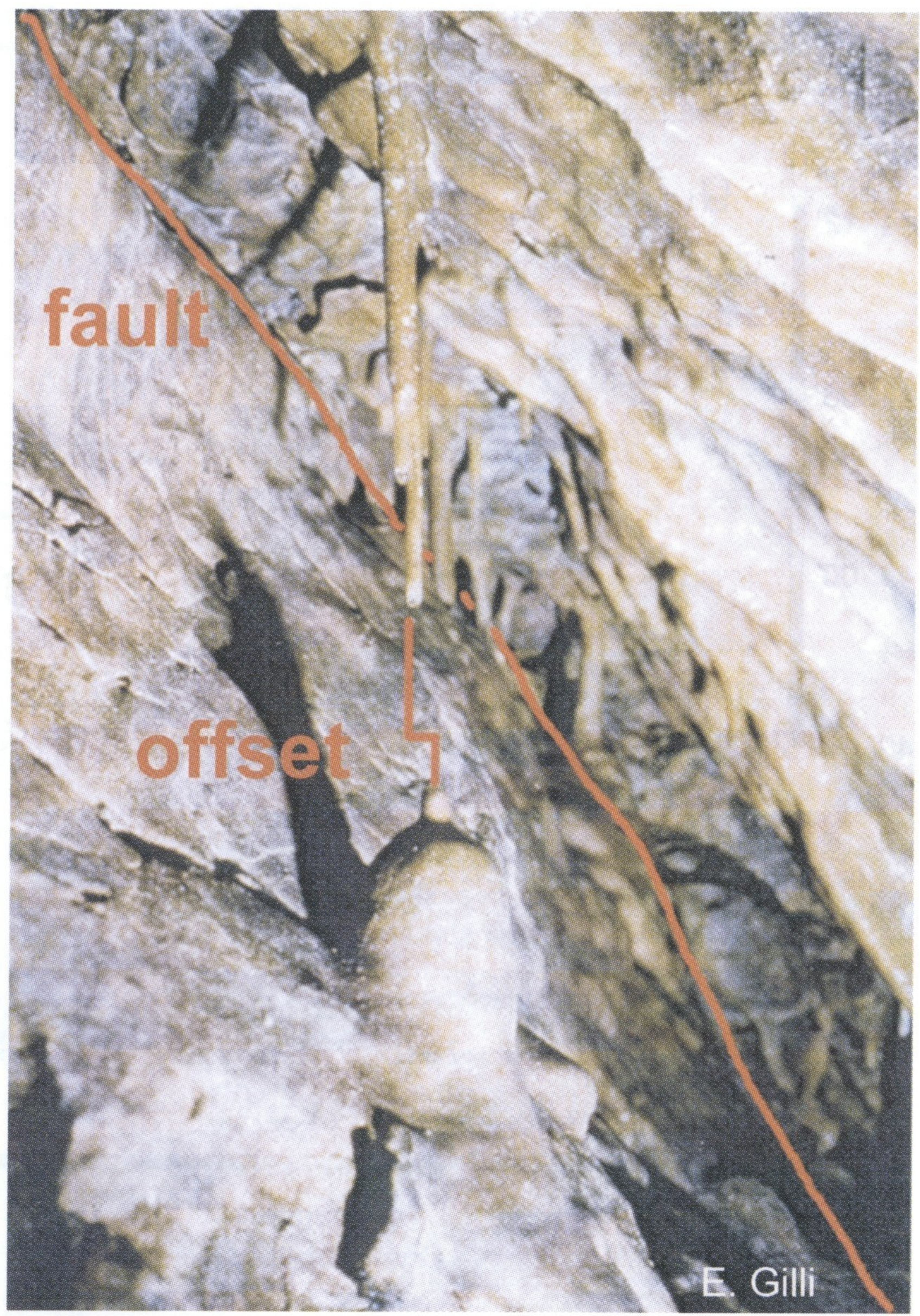

Fig. 5. Stalactite/stalagmite offset on a fault plane neighbouring the Vésubie-Mont Férion fault. This fault plane recently suffered a dextral strike-slip movement of some centimetres that could be of seismic origin (photo E. Gilli).

principal compressive stress axis trending $\mathrm{N} 160 \mathrm{E}$ for the Plio-Quaternary times (Rebaï, 1988 and Ritz, 1991). The focal mechanism of the November $1^{\text {st }}$, 1999 earthquake is consistent with the microtectonic data and could suggest a steady-state tectonic regime since several million years with a stress field that probably did not change significantly during this period.

The rectilinear and narrow seismogenic lineament striking N120E between Saorge, on the Roya river, and Taggia, on the Ligurian coast, is probably one of the most spectacular feature in this region (S.T.F in Figure 2). The trace of the fault is obvious at the regional scale (on topographic maps and spot satellite images) through the Ligurian flysch unit. However, in the field, it is quite difficult to identify a recent fault scarp at the outcrop scale (Cosani, 1997). This is probably due to the low-resistance flysch rocks which produce a very smooth topography. In the Taggia area, Plio-Pleistocene sediments show recent faulting and tilting (Hoang-Trong et al., 1987; Cosani, 1997; Eva et al., 2000).

In the Argentera massif, the NW-SE Argentera 


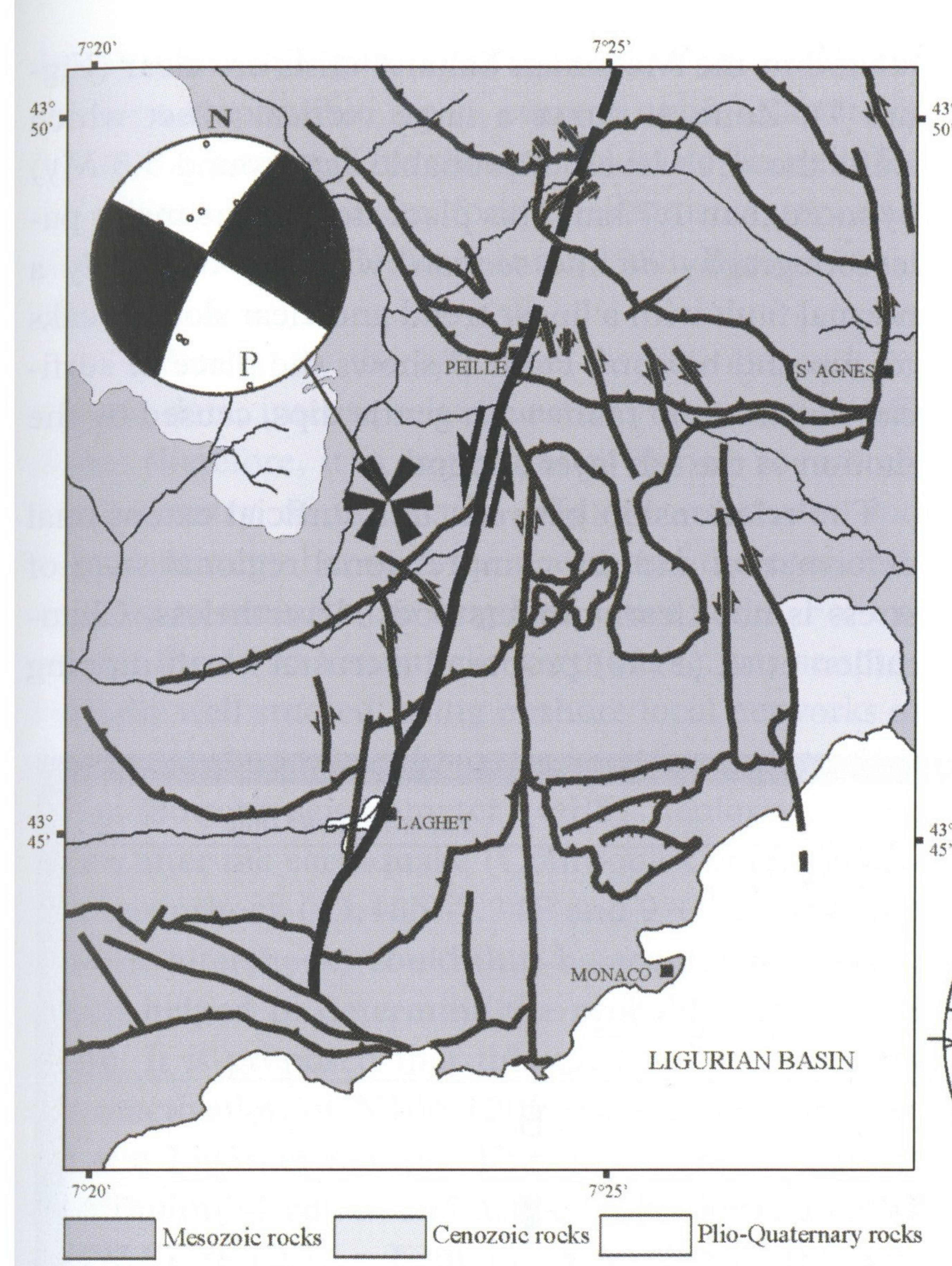

(A)

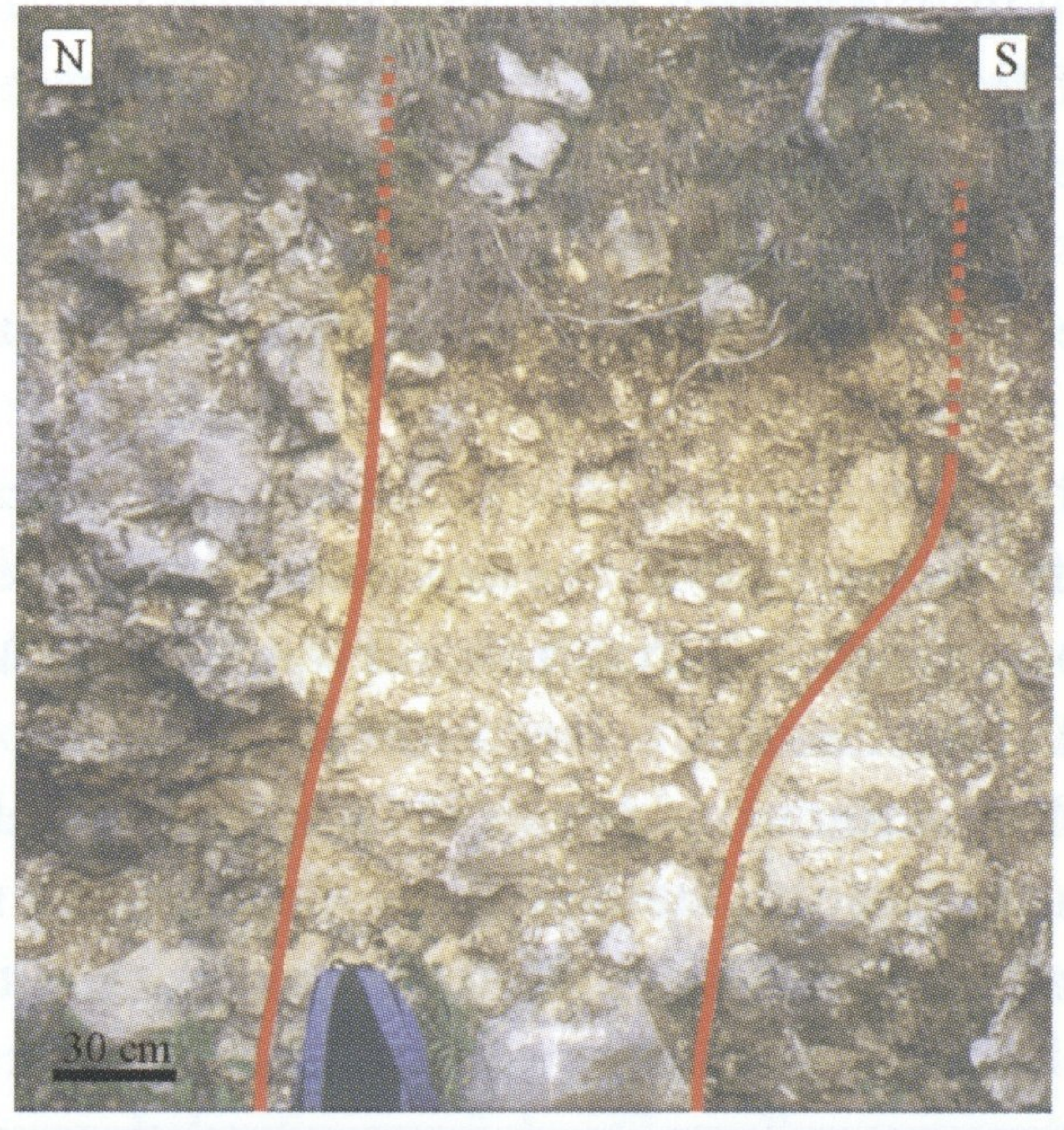

(B)
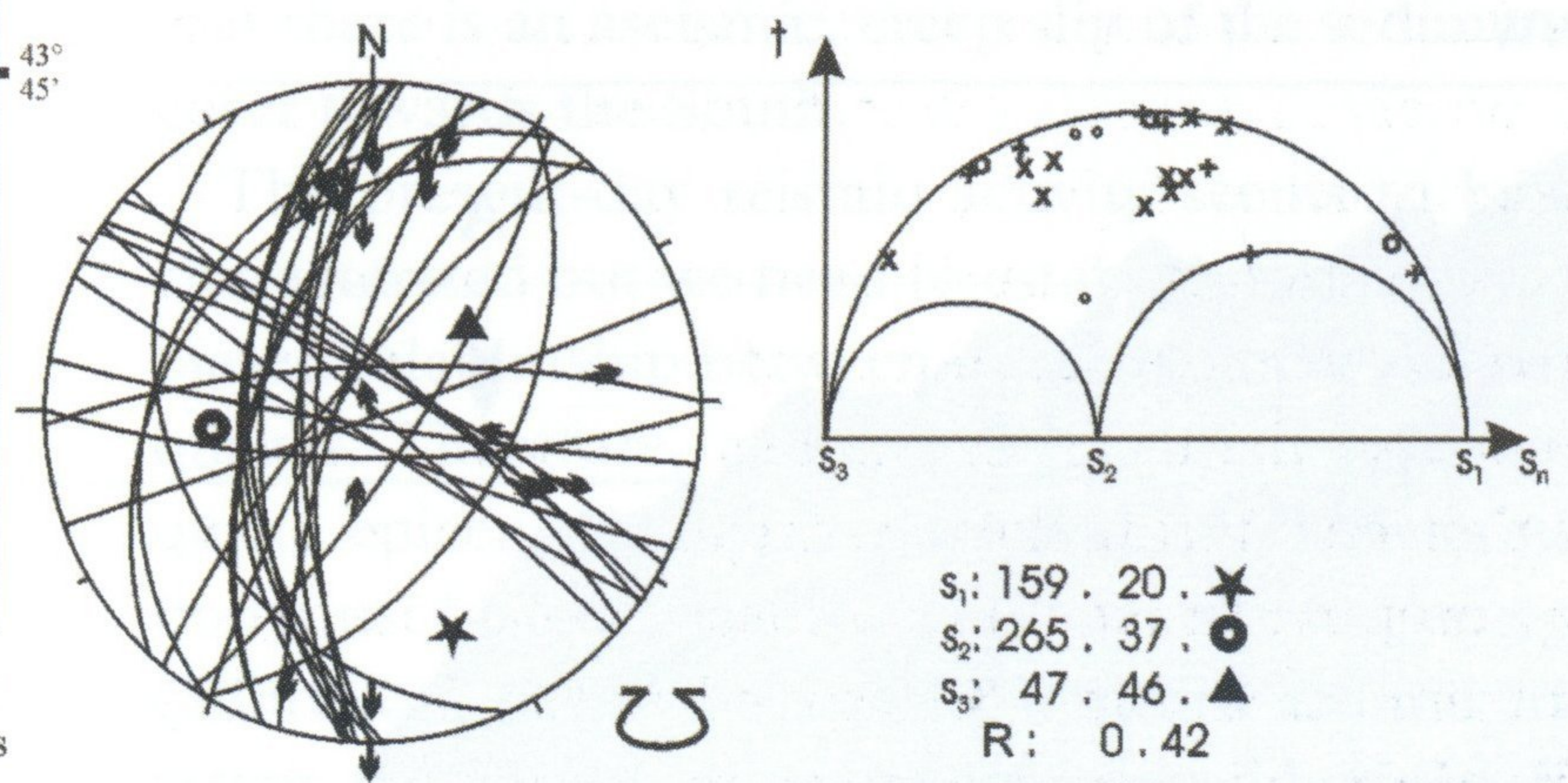

$s_{1}: 159 \cdot 20 \cdot \mathbb{*}$
$S_{2}: 265 \cdot 37,0$
$s_{3}: 47,46.4$
R: 0,42

( C )

Fig. 6. (A) Structural map of the Peille-Laghet fault area (from Gèze \& Lanteaume, 1963 and Rebaï, 1988). The focal mechanism of the November $1^{\text {st }}, 1999$ earthquake is consistent with a left-lateral movement along a more or less N30E fault. (B) Near Laghet, striated fault planes (red lines) crosscut Plio-Quaternary breccia. (C) The inversion of microtectonic data leads to a principal compressive stress axis trending N160E (Ritz, 1991).

fault (A.B.F. in Figure 2) displays field evidence for recent reverse dextral movement (Vogt, 1981; Combes, 1984; Ritz, 1991; Grellet et al., 1993). Gidon (1977) described offsets of morainic crest lines and Sauret \& Terrier (1987) pointed out tectonic scarps, along the direction of the Argentera fault, that affect moraines dating from the last glacial maximum (18 000 yr B.P.). As a whole, evidence for active deformation is preserved for more than $10 \mathrm{~km}$ along the fault. Furthermore, Baubron (1987) performed geochemical analyses and detected helium and radon anomalies straight above the trace of the fault that suggest a current tectonic activity.

At the northwestern edge of the Argentera massif, large normal faults, such as the Camp des Fourches fault (up to $1500 \mathrm{~m}$ of vertical offset), have been developed during Pliocene time (C.F.F. in Figure 2). These faults affect the Meso-Cenozoic sedimentary cover, and are interpreted by Labaume et al. (1989) as the result of gravitational collapse in response to the upper Miocene crustal thickening. No evidence for Quaternary deformation has been reported in the field along the Camp des Fourches and the neighbouring faults, although north of the Argentera massif, Sue et al. (1999) have demonstrated active widespread extension in the internal zones of the Alpes, based on focal mechanisms determination and field data.

Below the Argentera massif, several authors (e.g. Siddans et al., 1984; Ritz, 1991; Laurent, 1998) have proposed the existence of a crustal blind thrust fault, connected to the South with the decollement layer in the Triassic evaporites underlying the Castellane and Nice arcs (B, Figure 1). This crustal ramp (B, Figure 1) could be associated with the recent basement uplift of the Barrot Dome and the Argentera massif (BigotCormier et al., 2000). But no surficial E-W structure related to this deep-seated shortening has been reported in the field, for instance.

In the Castellane arc, field study does not allow us to identify recent deformation features, this is consistent with the historical and instrumental seismicity data but not with the data obtained in caves by Gilli $\&$ Delange (1999). It is known that the deformation was 
active in this area at least $15 \mathrm{My}$ ago because the middle Miocene molasse deposits are covered by the frontal thrust of the Castellane arc (Figure 1).

\section{Where are the active faults in the Ligurian basin?}

Offshore, at the foot of the margin, a system of normal faults parallel to the basin axis expresses a major tectonic feature (Chaumillon et al., 1994; Augliera et al., 1994). Seismic reflection data between Nice and San Remo show evidence of Quaternary deformation at the transition between the continental slope and the abyssal plain. Several lithostratigraphic markers related to the Messinian Salinity crisis are clear (Figure 7): Zone A shows a large vertical offset which shifts the "EU» level (of probable age around 5.3 My) by more than $1.7 \mathrm{~km}$. This place depicts the major paleotopography on the section, which is obviously a normal fault with a linear trend and clear slope breaks on top and bottom. Point B shows the place of surficial flexures and faults with gentle dips, caused by the motion of the salt layer at depth.

The relationship between this surficial extensional deformation and the compressional regional state of stress is not clearly understood. Nevertheless, Chaumillon et al. (1994) proposed a crustal north-dipping
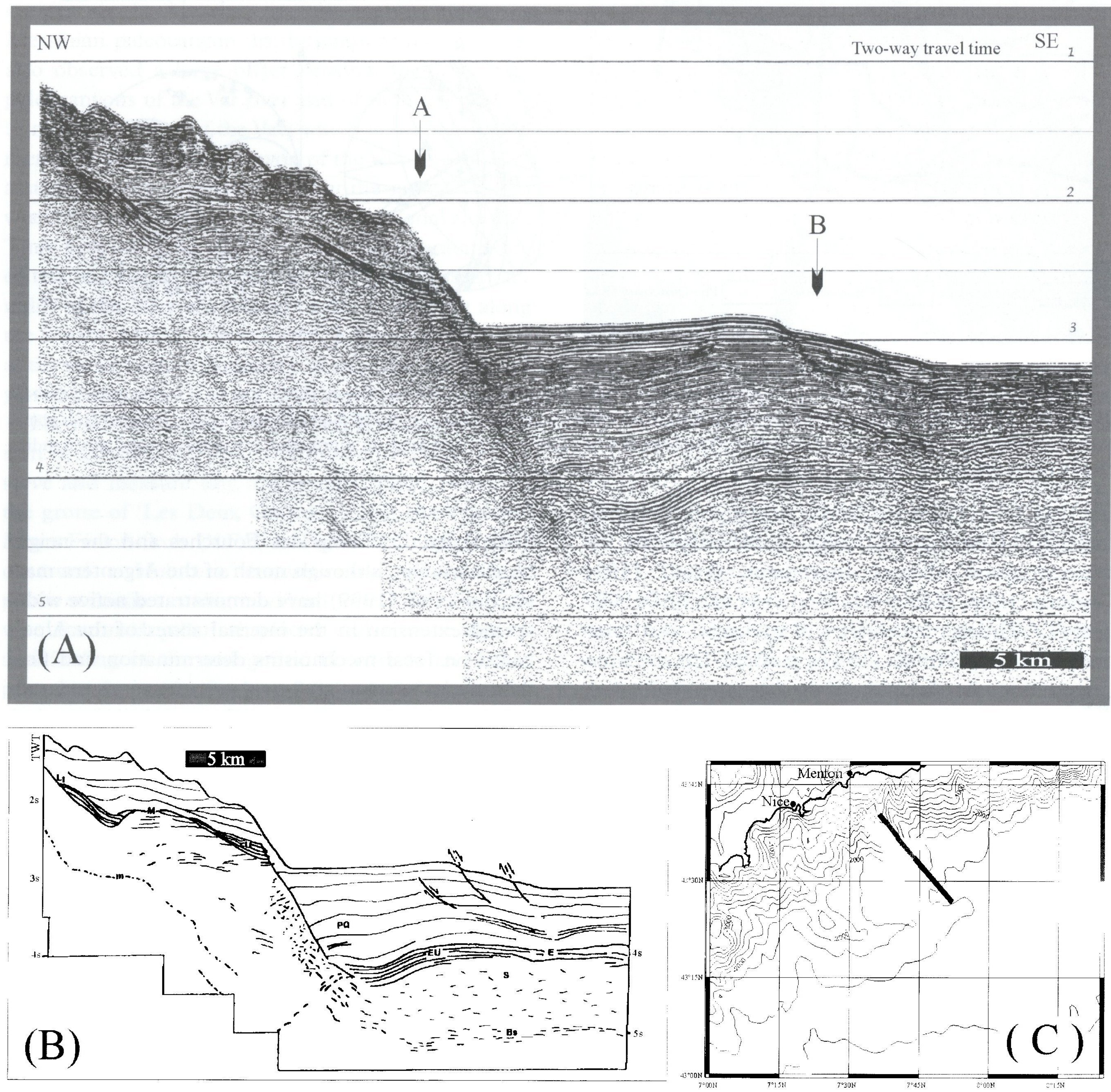

Fig. 7. (A) Monochannel seismic section obtained off Menton. This section has been done using a 80 ci- water gun on board Research Vessel Tethys II (INSU-CNRS), (B) line drawing of the seismic section (A) and (C) bathymetric map of the Ligurian northern margin and location of the seismic section $(\mathrm{A})$. 
thrust fault (B, Figure 1) at the base of the continental slope responsible for its current uplift at a rate of 0.3 to $0.5 \mathrm{~mm} / \mathrm{yr}$. This thrust could also account for the reverse earthquake focal mechanisms reported along the margin (Béthoux et al., 1988; Bétoux et al., 1992).

As indicated by the epicenter distribution and the seismic data, intense seismic activity also occurs offshore: therefore, it is important to define accurately the geometry of the active offshore structures and their continuity between the ocean and the continent in order to estimate the length of active faults. For example, the 1995 Ventimiglia earthquake was seismologically well studied, using onshore local networks of short-period and broad-band seismic stations and an ocean bottom seismometer (OBS) deployed a few hours after the earthquake (Courboulex et al., 1998). The mainshock (43.46N-7.34E and $9+/-2 \mathrm{~km}$ deep) and the aftershocks could thus be accurately located, which helped to determine the probable active fault plane. It is proposed that this earthquake represents the reactivation of N100-120E transverse faults that cut the Ligurian margin. This area shows a general distribution of paleo- and active faults dominated by a NW-SE trend (e.g. Lemoine et al., 1989). It is important to note that this moderate-size event occured on a short fault segment that has a limited surface expression, and which was not previously recognized as being active. Nevertheless, the seismicity on this segment is comparable to that observed along the parallel active system of the Saorge-Taggia fault ( S.T.F. in Figure 2). This illustrates the role of inherited, deeprooted, transcurrent features in the tectonic reactivation of the northern Ligurian margin (Courboulex et al., 1998).

Other offshore faults could also have an important seismogenic potential, but the relationships between offshore and onshore faults are unknown. Therefore a complete and accurate structural map of the Ligurian margin, contiguous with map for the southern Alps, is an important prerequiste for understanding regional tectonic processes and thus for the evaluation of the the seismic hazard.

\section{Discussion}

The linear trend pattern of epicenters together with the recent geodetic measurements attest that the Southern Alps - Ligurian basin junction is a region affected by active tectonics. All the field data collected by various geologists in the last decades are not always conclusive but display some evidence of surficial consequences related to these recent and active deformations (e.g. scarps along the Argentera-Bersezio fault, Plio-Quaternary tectonic breccia along the Peille-Laghet fault and offset of Quaternary terraces at the Var river mouth...). Since $20 \mathrm{My}$, the major deformations shifted from West to East: ages are upper Miocene in the Castellane arc (Laurent, 1998), PlioQuaternary in the Nice arc (Perez, 1975; Ritz, 1991) and presently, the regional seismic activity is maximum in the Ligurian area whereas west of the Var river, the Castellane arc is considered to be now inactive. Nevertheless, from investigation of karstic galleries, Gilli \& Delange (1999) propose a present-day activity at the front of the Castellane arc: this observation implies (i) either that the historical and instrumental seismicity are not representative of the deformation around the front of the Castellane arc, (ii) or that there is an aseismic, creep slip of the sedimentary cover towards the South.

The present-day seismic activity seems to be well characterized but we need to establish a clear and unbiased relationship between mapped faults and earthquakes. Therefore, a better determination of earthquake epicenters is necessary and depth determination must be improved. We are currently working on a calibration of the permanent network around interesting faults with accurate locations obtained from dense temporary networks of seismographs.

Despite the lack of Quaternary markers, we propose a preliminary map with 11 major active tectonic features including the 2 assumed onshore hidden faults (i.e. the frontal thrust of the Argentera massif and the lower Var valley fault) and the offshore Ligurian thrust (Figure 8).

This map is mainly based on the linear trends of epicenters and on the limited field evidence for recent and active deformation (Table 3 ). If the regional deformation is mainly related to localised movements along the principal faults identified in this work, then we can identify the deformation and the kinematics of the blocks (figure 8). Although the displacement along these faults is likely to be very small, a further GPS experiment of semi-permanent measurements should help us to understand the regional way of deformation.

But, in contrast with other regions of moderate seismicity (e.g. Camelbeek et al., 2000; Masana et al., 2000), clear surficial evidence of coseismic fault activation has not been identified in the field for instance. However, some moderate-size earthquakes sometimes produce a surface rupture, e.g.: (i) Cabrera \& Sébrier (1998) pointed out a surface rupture associated with a 5.3 magnitude earthquake in Peru, (ii) Basili at al. (1998) and Meghraoui et al. (1999) described discontinuous coseismic surface ruptures of near $60-500 \mathrm{~m}$ along a total length of $5 \mathrm{~km}$ associated 


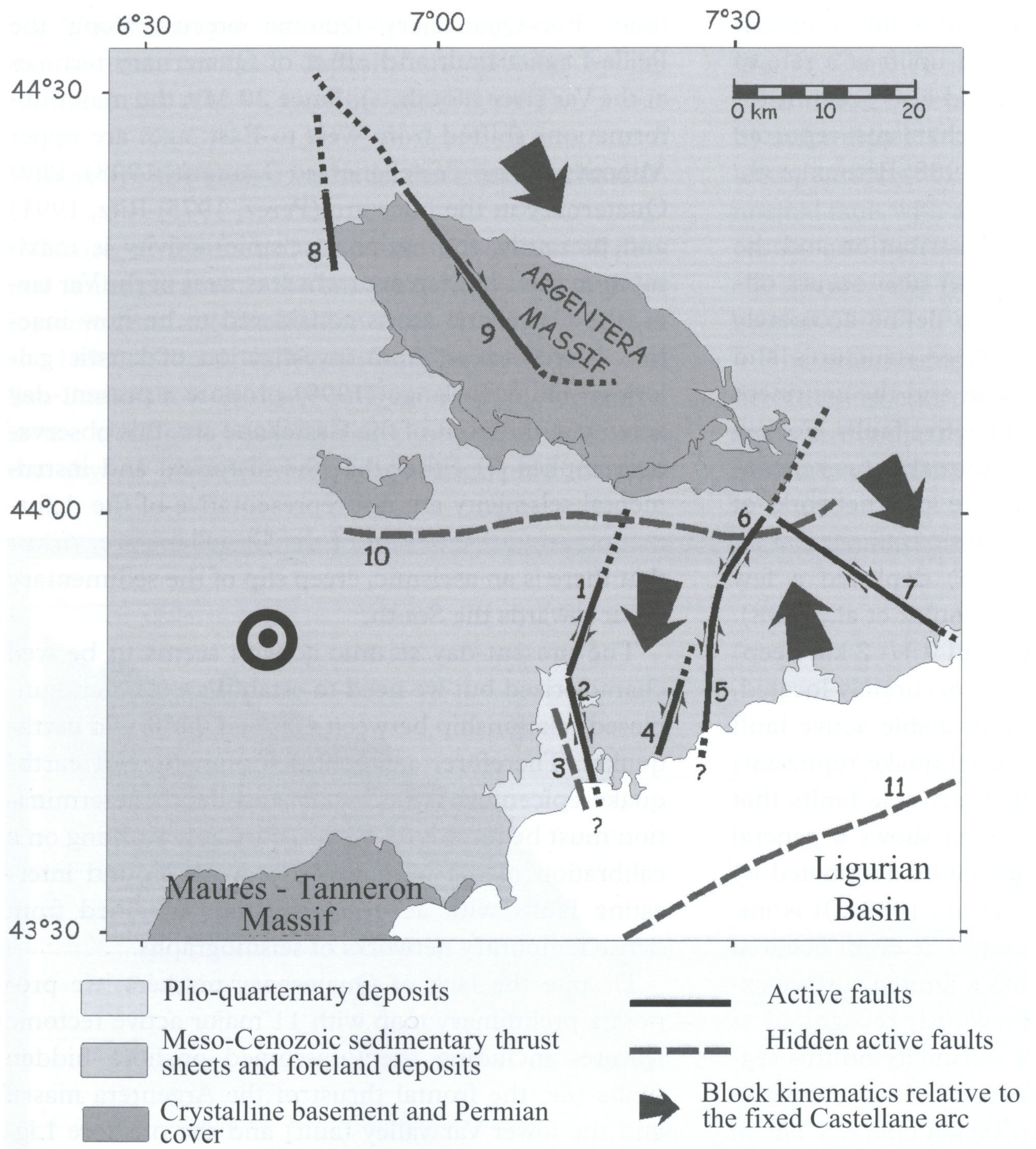

Fig. 8. Preliminary map of active faults at the Southern Alps- Ligurian basin junction (see Table 3 for details).

the fixed Castellane arc

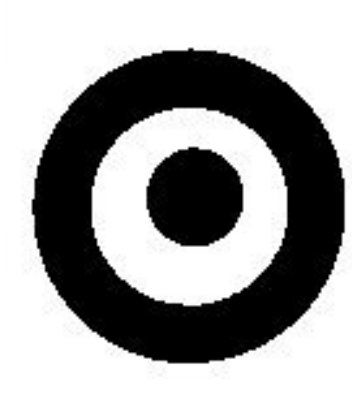

Table 3. Geometric and kinematic parameters, seismicity rate and field evidence for the 11 proposed active faults at the Southern Alps - Ligurian basin junction. The quality of the historical data is related to the region around the fault, but the quality of the data is not accurate enough to relate a historical event to a fault.

\begin{tabular}{|c|c|c|c|c|c|c|}
\hline \multirow[t]{2}{*}{ Name of the fault } & \multirow[t]{2}{*}{ Orientation } & \multirow[t]{2}{*}{ Kinematic } & \multirow{2}{*}{$\begin{array}{l}\text { Length } \\
(\mathrm{km})\end{array}$} & \multicolumn{2}{|c|}{ Seismicity } & \multirow[t]{2}{*}{ Field evidence } \\
\hline & & & & Historical & Instrumental & \\
\hline 1 -Vésubie - Mt Férion & $\mathrm{N} 20 \mathrm{E}$ & Dextral & 20 & yes & Low & $\begin{array}{l}\text { uplift of the Plio- } \\
\text { Quaternary }\end{array}$ \\
\hline 2 - St Blaise - Aspremont & N175E & and reverse & 15 & no & No & $\begin{array}{l}\text { conglomerates of the } \\
\text { Var river }\end{array}$ \\
\hline 3 - Lower Var valley & $\mathrm{N} 175 \mathrm{E}$ & Reverse & - & - & - & $\begin{array}{l}\text { vertical offset of } \\
\text { Quaternary terraces }\end{array}$ \\
\hline 4 - Laghet-Peille & $\mathrm{N} 20 \mathrm{E}$ & Sinistral & $10-18$ & no & Low & $\begin{array}{l}\text { crosscut Plio- } \\
\text { Quaternary breccia }\end{array}$ \\
\hline 5 - Monaco-Sospel & N10E & Sinistral & 20 & no & Moderate & - \\
\hline 6 - Sospel-Saorge & $\mathrm{N} 40 \mathrm{E}$ & Sinistral & 40 & no & Moderate & - \\
\hline 7 - Saorge-Taggia & N120E & Dextral & 40 & yes & Moderate & scarps \\
\hline 8 - Camp des Fourches & N165E & Normal & 20 & yes & Moderate & - \\
\hline 9 - Argentera-Bersezio & $\mathrm{N} 140 \mathrm{E}$ & Dextral & 70 & yes & Low & scarps \\
\hline 10 - Argentera thrust & N90E & Reverse & - & - & Low & hidden fault \\
\hline $\begin{array}{l}11 \text { - Ligurian thrust fault } \\
\text { system }\end{array}$ & $\mathrm{N} 70 \mathrm{E}$ & Reverse & - & yes & Moderate & Offshore \\
\hline
\end{tabular}


with the third event $\left(M_{s}=5.5\right)$ of the 1997 UmbriaMarche earthquake sequence and (iii) Azzaro (1999) observed some coseismic surface ruptures related to small earthquakes at the Mt Etna, in an area conditionned by volcano-tectonic activity. Therefore, in terms of seismic hazard, one important question remains: Are there any active faults scarps which could be identified onshore in the Alpes Maritimes, and if not, why?

Erosion tends to erase the fine morphological traces of tectonic deformation. Generally, in the Mediterranean region, the removal of material is difficult to quantify accurately because of a complex topographic and climatic setting and because erosion was not uniform during Quaternary time due to strong climatic changes. Based on geologic reconstructions and estimated river loads, Saunders \& Young (1983) proposed a mean denudation rate of around $0.1 \mathrm{~mm} / \mathrm{yr}$ for high relief terrains in the Mediterranean area since the last glacial maximum (18 ky B.P.). Thus, a vertical scarp of $1 \mathrm{~m}$ could be strongly degraded within only $10 \mathrm{kyr}$. Such scarps are assumed to be produced by a magnitude 6.5 earthquake (Well \& Coppersmith, 1994). Historically, our region has suffered such earthquakes, but the erosion rate is probably larger than the fault slip rate and therefore, the surficial expressions related to recent fault activity may not be easily visible.

The geodetic measurements in the Alpes Maritimes reveal a N-S shortening about $2-4 \mathrm{~mm} / \mathrm{yr}$ between the coast and the Argentera massif during the last 50 years. This strain rate is about twice larger than the values obtained in the Western Provence area (west of the Castellane arc) by Ferhat et al. (1998), which is consistent with the very low level of seismicity and few geological evidence for active deformation in Provence compared to the Alpes Maritimes. The question remains whether the present-day strain rate measured in the Alpes Maritimes is entirely associated or not with significant earthquakes. The answer is probably not, since the largest earthquakes known in the area during this period occurred offshore $\left(M_{b}=6.0,19 / 7 / 1963\right)$ and can account for a maximum coseismic displacement rate of $1 \mathrm{~mm} / \mathrm{yr}$ onshore which cannot explain the geodetic signal (Calais et al., 2000). This displacement rate has been obtained using a simple elastic dislocation model (Okada, 1993) and a coseismic slip of $10 \mathrm{~cm}$ on a SW-NE thrust fault located $100 \mathrm{~km}$ offshore. We therefore conclude that the shear strain rates measured in the geodetic network mostly reflect interseismic deformation.

Our attempt to gain a better understanding of the seismic hazard in the Southern Alps - Ligurian basin junction shows the problems related to investigation of active tectonics in areas of low to moderate seismicity. Although we have seismological, geodetic and tectonic informations, we cannot yet provide a detailed definition of the active tectonic framework. Apparently, the current methodologies for investigation of active tectonics in this kind of area can only give partial information.

\section{Conclusions}

The presence of active deformation in the Southern Alps and at their junction with the Ligurian basin is shown by numerous phenomena: offsets of Plio-Quaternary sedimentary formations, historical seismicity, present-day seismic linear trends and significant geodetic strain rates between the coast and the Argentera massif. Onshore, this deformation is mostly accommodated by a few faults inherited from the Miocene alpine orogeny. These active faults can be identified in the field, except for the possible hidden Argentera thrust and the lower Var valley fault. Offshore, the faults inherited from the openning of the Ligurian basin have been reactivated but the data sets (seismicity catalogue, seismic-reflection sections and bathymetry) are not yet dense enough to provide a fully controlled structural sketch (for example, the Ligurian thrust is probably a complex fault system).

Though a preliminary map of 11 active faults can be proposed, the few accurate knowledges on the length of the potentially active fault segments in relation with the regional present-day state of stress prevents to estimate a possible maximum magnitude for this region. Therefore, some major questions remain open and must be addressed in the future in order to obtain more complete data for seismic hazard evaluations: (i) Are the proposed active faults divided in different segments of different size and activity ? (ii) What are the relationships between offshore and onshore active structures? (iii) The largest earthquakes recently recorded are located offshore (with a magnitude of up to 6.0); are some onshore faults able to produce an earthquake with such a magnitude ? (iv) The recurrence intervals for major earthquakes are unknown; are they of the order of tens of thousand years or of thousands of years ? What are the ages of the last events on active faults ? We believe that these questions can be solved in the future, by combining (i) geodetic measurements, (ii) accurate location of earthquakes, and (iii) detection of sites suitable for paleoseismological investigations. Finally, it is currently difficult to determine reliable sites for paleoseismology mainly because the morphological evidence of present-day activity is lacking, nevertheless 
the current field study and geophysical prospecting through the Plio-Quaternary deposits of the lower Var valley could reveal some area suitable for trenching.

Furthermore, the wide range of geological basements in this region (crystalline rocks, sedimentary rocks, colluvium, alluvium) and the sharp topography are responsible for the amplification of ground shaking in areas subject to site effects. For example, the November 1st, 1999 Peille earthquake was clearly felt by the population, although its magnitude was small $\left(M_{w}=3.4\right.$, Courboulex et al., 2000). Finally, we may note that the valley of Peille is often shaken during earthquakes, which could be explained by ground amplification (Duval, 1996; Gaffet et al., 1998; Larroque et al., 1999). Therefore, the study of such a densely populated and geologically varied area also requires taking into account site effects as a major component of seismic hazard assessment.

\section{Acknowledgements}

The autors would like to thank the anonymous reviewer and particularly Fabrizio Galadini for his very constructive review that significantly contributed to improve this paper and his editorial support and Anthony Lomax for improvement of the English. This work was funded by the French national program «Programme National sur les Risques Naturels» (CNRS-INSU). Contribution N³46 UMR Géosciences Azur.

\section{Rerefences}

Augliera P., Béthoux N., Déverchère J. \& Eva C., 1994. The Ligurian Sea: new seismotectonic evidence. Boll. Geofis. Teorica Appl., XXXVI (141-144), 363-380.

Azzaro R., 1999. Earthquake surface faulting at the Mount Etna volcano (Sicily) and implications for active tectonics. J. of Geodynamics, 28, 193-213.

Basili R., Bosi V., Galadini F., Galli P., Meghraoui M., Messina P., Moro M. \& Sposato A., 1998. The Colfiorito earthquake sequence of september-october 1997: surface breaks and seismotectonic implications for the Central Apennines (Italy). J. of Earth. Eng., 2, 291-302.

Baubron J.C., 1987. Compte rendu détaillé, Argentera (Alpes Italiennes). BRGM, diffusion délégation Risques Majeurs, 3 pp.

Baroux E., Béthoux, N. \& Bellier O., 2000. Analyses of the stress field in southeastern France from earthquake focal mechanisms. In press Geophys. J. Int.

Bigot-Cormier F., Poupeau G. \& Sosson M., 2000. Differential denudations of the Argentera external crystalline massif (SE France) reavaled by fission tracks thermochronology (zircons, apatites). C. R. Acad. Sci. Paris, 330, 363-370.

Béthoux N., Cattaneo M., Delpech P.Y., Eva C., \& Réhault J.P., 1988. Mécanismes au foyer de séismes en mer Ligure et dans le Sud des Alpes occidentales: résultats et interprétations. C. R. Acad. Sci. Paris, 307, 71-77.

Béthoux N., Fréchet J., Guyoton F., Thouvenot F., Cattaneo M.,
Eva C., Nicolas M. \& Granet M., 1992. A closing Ligurian sea. Pure Appl. Geoph., 139, 179-194.

Béthoux N., Ouillon G. \& Nicolas M., 1998. The instrumental seismicity of the western Alps: Spatio-temporal pattern. Geophys. J. Int., 135, 177-194.

Borchielini S., Campredon R. \& Bernat M., 1991. Ground variation of Radon 222 for location of hidden structural features. Example of the South of France (Alpes Maritimes). Pageoph., 135, 625-638.

Boschi E., Ferrari G., Gasperini P., Guidoboni E., Smriglio G. \& Valensise G., 1995. Catalogo dei forti terremoti in Italia dal 461 a.C. al 1980. Istituto Nazionale di Geofisica-Storia Geofisica Ambiente, Bologna, 973 pp.

Boschi E, Guidoboni E., Ferrari G, Valensise G. \& Gasperini P., 1997. The catalogue of strong Italian Earthquakes on the web. http://storing.ingrm.it/cft/.

Bossolasco M. \& Eva C., 1965. Il terremoto del 19 luglio 1963 nel mar Ligure. Geofis. e Meteor., 14, 6-18.

Bulard P.F., Chamagne B., Dardeau G., Delteil J., Gioan P., Ivaldi J.P., Laval F., Perez J.L. \& Polvèche J., 1975. Sur la genèse et les structures de l'arc de Nice. Bull. Soc. Géol. de France, XVII.

Cabrera J. \& Sébrier M., 1998. Surface rupture associated with a $5.3 \mathrm{mb}$ earthquake: the 5 April 1986 Cuzco earthquake and kinematics of the Chincheros-Qoricocha faults of the High Andes, Peru. Bull. Seism. Soc. Am., 88, 242-255.

Calais E., Galisson L., Stéphan J.F., Delteil J., Deverchère J., Larroque C., Mercier de Lépinay B., Popoff M. \& Sosson M., 2000. Crustal strain in the southern Alps, France, 1948-1998. Tectonophysics, 319, 1-17.

Camelbeeck T., Martin H., Vanneste K., Meghraoui M, Verbeeck K. \& Brondeel M., 2000. Geomorphic evidence of active faulting in slow deformation area: the exemple of the Lower Rhine Embayment. Workshop «Evaluation of the potential for large earthquakes in region of present-day low seismic activity in Europe", Han sur Lesse, 13-17 March 2000, abstract volume, 31-34.

Chaumillon, E., Deverchère J., Réhault, J.P. \& Gueguen E., 1994. Réactivation tectonique et flexure de la marge continentale Ligure (Méditerranée Occidentale). C.R. Acad. Sc., Paris, 319, 675682.

Clauzon G., Rubino J.L. \& Suc J.P., 1996. Les rias pliocènes du Var et de Ligurie: comblement sédimentaire et évolution géodynamique. Field trip book of the Groupe Français d'Etude du Néogène/Groupe Français de Géomorphologie, 36p.

Combes P., 1984. La tectonique récente de la Provence occidentale: microtectonique, caractéristiques dynamiques et cinématiques. Méthodologie de zonation tectonique en relation avec la sismicité. Thèse de doctorat, Univ. de Strasbourg, $182 \mathrm{pp}$.

Cosani L., 1997. Neotectonique et heritage structural entre massif du Mercantour et marge ligure: le secteur de Saorge-Taggia. Géologie Alpine, 128-134.

Courboulex F., Deschamps A., Cattaneo M., Costi F., Deverchère J., Virieux J., Augliera P., Lanza V. \& Spallarossa D., 1998. Source study and tectonic implications of the 1995 Ventimiglia (border of Italy and France) earthquakes $\left(M_{L}=4.7\right)$. Tectonophysics, 290, 245-257.

Courboulex F., Duval A.M., Lomax A., Deschamps A. \& Larroque C., 2000. Les enseignements du petit séisme de Peille $(M w=3.4)$ du $1^{\text {er }}$ novembre 1999 (Alpes Maritimes, France). Congrès Riviera 2000 "Tectonique active et géomorphologie» 18-22 octobre 2000, Villefranche sur Mer, abstract volume, 11.

DeMets C., Gordon R.G., Argus D.F. \& Stein S., 1994. Effect of recent revisions to the geomagnetic reversal time scale on estimates of current plate motions. Geophys. Res. Letters, 21,21912194.

Dubar M., \& Perez J.L., 1989. Quaternary neotectonics bordering 
on the subalpine 'Arc de Nice'. C.R. Acad Sci., Paris, 308, 14851490.

Dubar M., Gugliemi Y. \& Falgueres C., 1992. Néotectonique et sédimentation côtière quaternaire en bordure de l'arc subalpin de Nice (Alpes Maritimes, France). Quaternaire, 3, (3-4), 105110.

Dubar M. \& Gugliemi Y., 1996. Morphogenèse et mouvements verticaux quaternaires en bordure de l'arc de Nice, essai de quantification. Rev. d'Anal. Spatiale Quant. App., 38, 21-27.

Duval A.M., 1996. Détermination de la réponse d'un site aux séismes à l'aide du bruit de fond: évaluation expérimentale. Thèse de doctorat de l'Univ. Paris VI, 265 pp.

Eva C. \& Rabinovich A.B., 1997. The Febuary 23, 1887 tsunami recorded on the Ligurian coast, western Mediterranean. Geophys. Res. Lett., 24, 2211-2214.

Eva C., Augliera P., Burgisi C., Eva E., Solarino S. \& Spallarossa D., 2000. New evidences on the seismotectonics of the SaorgeTaggia Line from analysis of the recent seismicity. Europ. Geophys. Soc. 25th general assembly, 26-29 April, Nice.

Fauquette S., Clauzon G., Suc J.P. \& Zheng Z., 1999. A new approach for palaeoaltitude estimates based on pollen records: example of the Mercantour Massif (southeastern France) at the earliest Pliocene. Earth Planet. Sci. Lett., 170, 35-47.

Ferhat G., Feigl K., Ritz J.F. \& Souriau A., 1998. Geodetic measurement of tectonic deformation in the southern Alps and Provence, France, 1887-1994. Earth Planet. Sci. Lett., 159, 3546.

Ferrari G., 1991. The 1887 Ligurian earthquake: A detailed study from contemporary scientific observations. Tectonophysics, 193, 131-139.

Gaffet S., Larroque C., Deschamps A. \& Tressols F., 1998. Dense array experiment for observation of waveform perturbation induced by local structure diffraction. Soil Dynamics and Earthquake Engineering, 17, 475-484.

Gèze B. \& Lanteaume M., 1963. Carte géologique de MentonNice, Editions BRGM.

Ghafiri A., 1995. Paléosismicité de failles actives en contexte de sismicité modérée: application à l'évaluation de l'aléa sismique dans le Sud-Est de la France. Thèse de doctorat, Univ. Paris XI, $373 \mathrm{pp}$.

Gidon M., 1977. Notice de la carte géologique de Larche, 1/50 000. Ed. BRGM.

Gidon M. \& Pairis J.L., 1992. Relations entre le charriage de la Nappe de Digne et la structure de son autochtone dans la vallée du Bès (Alpes de Haute-Provence, France). Eclogae Geol. Helv., 85/2, 327-359.

Gilli E., 1981. Néotectonique dans les massifs karstiques. D.E.A. Univ. Aix-Marseille, 78 pp.

Gilli E., 1986. Néotectonique dans les massifs karstiques, un exemple dans les préalpes de Nice: la grotte des Deux Gourdes. Karstologia, 8, FFS-AFK-CNRS, 50-52.

Gilli E. \& Delange P., 1999. Recent slow and aseismic movement of an overthrust observed in the Abel sink hole (Saint-Vallier-deThiey, Alpes Maritimes, France). Geodynamica Acta, Colloque de Han sur Lesse 1998.

Grellet B., Combes P., Granier T. \& Philip H., 1993. Sismotectonique de la France Métropolitaine dans son cadre géologique et géophysique. Mem. Soc. Géol. de France, 164, 76 pp.

Hoang-Trong P. Haessler H., Holl J.M. \& Legros Y., 1987. L'essain sismique (oct. 83 - jan. 84) de la moyenne vallée de la Roya (Alpes Maritimes): activité récente d'un ancien système de failles conjuguées? C.R. Acad. Sci. Paris, 304, 419-424.

Irr F., 1984. Paléoenvironnements et évolution géodynamique néogènes et quaternaires de la bordure nord du Bassin Méditerranéen Occidental, un système de pente de la paléo-marge provençale. Thèse Université de Nice, $464 \mathrm{pp}$.

Klaucke I., Savoye B. \& Cochonat P., 2000. Patterns and processes of sediment dispersal on the continental slope off Nice, SE France. Marine Geol., 162, 405-422.

Labaume P., Ritz J.F. \& Philip H., 1989. Recent normal faults in the southwestern Alps: their relationships with the compression tectonics. C.R. Acad. Sci. Paris 308, série II, 1553-1560.

Lambert J. \& Levret A., 1996. Mille ans de séismes en France. Ouest Editions Presses Académiques, Nantes, 120 pp.

Larroque C., Gaffet S., Cornou C., Schissele E., Bertrand E., Béthoux N., Bouchon M., Corrazzi M., Courboulex F., Deschamps A., Duval A.M., Maron C., Glot J.P., Janod F., Guiguet R., Vidal S. \& Virieux J., 1999. Une expérience multi-antennes à Annot pour l'analyse des effets de site en sismologie. C. R. Acad. Sci. Paris, 329, 167-174.

Larroque C., Béthoux N., Calais E., Courboulex F., Deschamps A., Deverchère J., Stéphan J.F., Ritz J.F. \& Gilli E., 2000. Joint Multidisciplinary studies of active faults and seismic hazard at the junction between southern French Alps and Ligurian basin. Abstract volume Paleosis, Han sur Lesse (Belgium), 13-17 march 2000, 89-92.

Laurent O., 1998. Modalités de la structuration d'un prisme de front de chaîne: l'example de l'arc de Castellane (chaînes subalpine Méridionales, France). PhD Thesis, Univ. Nice- Sophia Antipolis, $280 \mathrm{pp}$.

Laurenti A., 1998. Les tremblements de terre des Alpes Maritimes. Serre Editeur, Nice, 175 pp.

Lemoine M., Dardeau G., Delpech P., Dumont T., De Graciansky C., Graham R., Jolivet L., Robert D. \& Tricart P., 1989. Extension synrift et failles transformantes jurassiques dans les Alpes Occidentales. C.R. Acad. Sci. Paris, 309, 1711-1716.

Levret A., Cushing M. \& Peyridieu G., 1996. Etude des caractéristiques des séismes historiques en France. IPSN, Paris, 399 pp.

Masana E., Villamarin J.A., Sanchez Cabanero J., Plaza J. \& Santanach P., 2000. Seismological behaviour of a fault with no historical seismicity: El Camp fault (northeastern Iberian peninsula). Workshop «Evaluation of the potential for large earthquakes in region of present-day low seismic activity in Europe", Han sur Lesse, 13-17 March 2000, abstract volume, 101-104.

Madeddu B., Béthoux N. \& Stephan J.F., 1996. Déformations et champs de contraintes récents à actuel dans les Alpes sud-occidentales: approche sismotectonique. Bull. Soc. Géol. de France, 167, 797-810.

McKenzie D., 1969. The relation between fault plane solutions for earthquakes and the directions of the principal stresses. Bull. Seism. Soc. Am., 59, 591-601.

Meghraoui M., Bosi V, \& Camelbeek T., 1999. Fault fragment control in the 1997 Umbria-Marche, central Italy, earthquake sequence. Geophys. Res. Lett., 26(8), 1069-1072.

Nicolas M., Béthoux N. \& Maddedu B., 1998. Instrumental seismicity of the Western Alps. Pure Appl. Geophys., 152, 707-731.

OkadaY., 1993. Surface deformation to shear and tensile faults in a half space. Bull. Seism. Soc. Am.75, 148-142.

Perez J.L., 1975. La zone limite entre l'arc de Nice et l'arc de la Roya (Alpes Maritimes). Bull. Soc. Géol. de France, 7, 930-938.

Rebaï S., 1988. Le champ de contrainte actuel en Europe et dans les régions méditerranéennes. Etude du décrochement senestre plio-quaternaire de Laghet-Peille. D.E.A., Univ. de Montpellier, $36 \mathrm{pp}$.

Rebaï S., Philip H. \& Taboada A., 1992. Modern tectonic stress field in the Mediterranean region: evidence for variation in stress direction at different scales. Geophys. J. Int., 110, 106-140.

Ritz J.F., 1991. Evolution du champ de contraintes dans les Alpes $\mathrm{du}$ Sud depuis la fin de l'Oligocene. Thèse de doctorat, Univ. de Montpellier, $187 \mathrm{pp}$. 
Ritz J.F., 1992. Tectonique récente et sismotectonique des Alpes du Sud, analyse en termes de contraintes. Quaternaire, 3, 111-124.

Saunders I. \& Young A., 1983. Rate of surface processes on slopes, slope retreat and denudation. Earth Surf. Proc. and landforms, 8, 473-501.

Sauret B. \& Terrier M., 1987. Compte rendu de mission Argentera. BRGM, note BS/GR 87, 175.

Schroetter J.M., 1998. L'enregistrement sédimentaire de la déformation mio-plio-quaternaire sur la bordure ouest de l'arc de Nice: analyse sedimento-morpho-structurale. Géologie Alpine, $74,146-149$.

Siddans A., Henry P., Kligfield B., Lowrie W., Hirt A. \& Percevault M., 1984. Finite strain patterns and their significance in permian rocks of the Alpes Maritimes (France). J. Struc.Geol., 6, 339368.
Sue C., Thouvenot F., Fréchet J. \& Tricart P., 1999. Widespread extension in the core of the Western Alps revealed by earthquake analysis. J. Geophys. Res., 104, 2561 1-25622.

Vogt J., 1981. Carte sismotectonique de la France au 1/1000 000. CEA/EDF/BRGM/ Ministère de l'Industrie, Mém. BRGM, 111.

Wells D.L. \& Coppersmith K.J., 1994. New empirical relationships among magnitude, rupture length, rupture width, rupture area and surface displacement. Bull. Seism. Soc. Am., 84, 974-1002.

Westphal M., Orsini J. \& Vellutini P., 1976. Le microcontinent corso-sarde, sa position initiale, données paléomagnétiques et raccords géologiques. Tectonophysics, 30, 41-57.

Working Group CPTI, 1999. Catalogo parametrico dei Terremoti Italiani. ING, GNDT, SGA, SSN, Bologna, 92pp. http://emidius.itim.mi.cnr.it/CPTI/home.html. 